\title{
A nova era de cooperação Moçambique - China: debates, dilemas, realidades e perspectivas de políticas institucionais
}

A new age of Mozambique-China cooperation: discussions, dilemmas, realities and perspectives

La nouvelle ère de coopération Mozambique-Chine : débats, dilemmes, realités et perspectives

La nueva era de la cooperación Mozambique - China: debates, dilemas, realidades y perspectivas

\section{Nelson Laura Mabucanhane}

\section{(2) OpenEdition}

Journals

Edição electrónica

URL: http://journals.openedition.org/espacoeconomia/2025

DOI: $10.4000 /$ espacoeconomia.2025

ISSN: 2317-7837

Editora

Núcleo de Pesquisa Espaço \& Economia

Refêrencia eletrónica

Nelson Laura Mabucanhane, «A nova era de cooperação Moçambique - China: debates, dilemas, realidades e perspectivas de políticas institucionais », Espaço e Economia [Online], 7 | 2015, posto online no dia 12 abril 2016, consultado o 30 abril 2019. URL : http://journals.openedition.org/ espacoeconomia/2025; DOI : 10.4000/espacoeconomia.2025

Este documento foi criado de forma automática no dia 30 Abril 2019.

(c) NUPEE 


\section{A nova era de cooperação Moçambique - China: debates, dilemas, realidades e perspectivas de políticas institucionais}

A new age of Mozambique-China cooperation: discussions, dilemmas, realities and perspectives

La nouvelle ère de coopération Mozambique-Chine : débats, dilemmes, realités et perspectives

La nueva era de la cooperación Mozambique - China: debates, dilemas, realidades y perspectivas

Nelson Laura Mabucanhane

\section{NOTA DO EDITOR}

Artigo preparado para orientar os debates no Seminário sobre Gestão Pública no ISAP, setembro de 2015. Agradeço a Coordenação de Aperfeiçoamento de Pessoal do Nível Superior (CAPES) pela bolsa de estudos e ao meu orientador Prof. Dr. Floriano José de Oliveira Godinho, bem como aos demais colegas do Grupo de Pesquisa do PPFH/UERJ.

\section{Introdução}

1 Apesar das históricas relações de cooperação Moçambique - China desde a Luta de Libertação Nacional e durante a guerra civil até então, apresentarem significativos resultados em termos de ganhos para Moçambique, China é visto como um risco para o desenvolvimento saudável e sustentável de Moçambique em particular e de África em geral. De acordo com Chichava (2010), China representa uma reedição das relações que a 
África estabelece com o Ocidente e limita a perspectiva do desenvolvimento africano. Confirma esta visão conforme evidenciam, por exemplo, os estudos de Southall and Merlber (2009) e Brautingam (2009) a maioria da literatura ocidental e africana especializada e/ou interessada pela cooperação África - China em geral e Moçambique em particular. A nova era de cooperação Moçambique - China, objeto deste estudo, alimenta debates e acesas controvérsias. Se por um lado, encontra forte objeção crítica tanto do Ocidente quanto de alguns acadêmicos, sociedade civil, líderes políticos, empresários, entre outros extratos sociais, por outro lado, encontra forte apoio da maioria da elite política nacional no poder e uma parte dos acadêmicos e dos demais extratos sociais.

2 A partir de uma breve análise de evidências históricas na primeira fase da cooperação Moçambique - China (1975 - 1999), passando pelas mudanças do ambiente e arranjo institucional em Moçambique conseqüente das mudanças do modelo econômico e político até desaguar na nova era de cooperação Moçambique - China (desde os nos anos 2000) este estudo encontrou evidências empíricas suficientes para afirmar que de fato as relações diplomáticas entre os dois países canalizam ganhos substanciais para Moçambique.

3 Deste modo, o objetivo deste artigo é analisar os ganhos para Moçambique na sua relação diplomática com a China considerando os debates, dilemas e realidades atuais.

4 A questão de partida que orientou este estudo foi por que é que apesar de a cooperação Moçambique - China apresentar ganhos substanciais para Moçambique, China é visto como um mau doador, investidor e/ou como um risco que limita o desenvolvimento saudável e sustentável de Moçambique? Foram consideradas duas hipóteses de investigação para responder a esta questão e por essa via determinadas as duas partes do trabalho. Com recurso à revisão da literatura em todo o trabalho, a primeira parte discute de forma breve a fase inicial de cooperação Moçambique - China, a mudança do modelo econômico e político e a adesão ao assistencialismo retardatário e de dependência técnica e financeira de Moçambique ao Ocidente. A partir de evidências históricas, esta parte defende as premissas básicas de que a dependência de trajetória não deve ser ignorada a curto e médio prazo para explicar a extrema pobreza moçambicana e que não tem nenhuma associação com a emergência da China. De certeza que poderá parecer ao leitor uma ilusória deslocação desta primeira parte no debate da questão central que é a cooperação Moçambique - China. Porém, é preciso sintetizar que esta primeira parte apresenta as bases explicativas que justificam ou dão sustentabilidade à hipótese de investigação cujas evidências históricas compõem a segunda parte. Outro aspecto que o leitor poderá constatar tanto na primeira quanto na segunda parte é a deslocação do espaço de estudo para uma visão quase que genérica do continente africano. Trata-se de uma opção metodológica que quanto a este artigo, ajuda a perceber que a ausências de evidências sobre um impacto negativo da presença da China não é só em Moçambique, mas quase em todo o continente. A segunda parte - o centro deste estudo confirma a hipótese de investigação que procurava demonstrar que não é que a China seja mau doador e/ou investidor ou ainda constitua um risco para o desenvolvimento saudável e sustentável de Moçambique, mas a dimensão política moçambicana como componente para entender a capacidade institucional do Estado para além da sua associação a interesses particulares e partidários, é frágil para se lidar com os interesses do gigante econômico chinês.

5 Para sustentar esta hipótese, o estudo tomou como método de investigação a revisão da literatura, na qual buscava evidências históricas que pudessem fundamentar todos os 
argumentos apresentados. Foram usados para efeitos de demonstração dados existentes e públicos em várias obras. Apenas os dados sobre o Investimento Direto Estrangeiro (IDE) em Moçambique é que foram recolhidos no Centro de Promoção de Investimentos (CPI) e no Gabinete das Zonas Econômicas de Desenvolvimento Acelerado (GAZEDA). 0 emprego deste método permitiu apresentar as evidências históricas e a coerência e consistência lógica da hipótese do artigo, tendo tomado como indicadores de análise o comportamento dos ganhos para Moçambique ao longo do tempo na sua relação diplomática com a China. Adicionalmente, foram avaliados os debates sobre as principais fontes do fluxo de capital estrangeiro, como por exemplo, a ajuda externa, doações, assistência técnica e financeira, as remessas da diáspora africana, o Investimento Direto Estrangeiro (IDE) e o desempenho de algumas economias africanas. A finalidade de análise destes indicadores eram verificar o seu comportamento, ou seja, se apresentavam tendências de retração ou desaceleração passível de ser associada ao crescente aumento da presença chinesa em Moçambique em particular e em África no geral. Os resultados desse exercício permitiram perceber que não existem evidências históricas para uma visão pessimista sobre a China, apesar de reconhecer os debates e dilemas literários em volta. Foi possível ainda notar que o fluxo de capitais estrangeiros para assistência técnica e financeira de África, apesar de vários autores terem perspectivado desde os anos 2000 tendência de redução, ele continua elevado ao atingir 200 mil milhões de dólares em 2014 em toda a África, acima da anterior previsão de US\$ 195 mil milhões em 2015. Ao contrário do que tem sido literalmente apresentado de que a presença da China em África em geral e Moçambique em particular, é um risco e limita o desenvolvimento saudável e sustentável de Moçambique, foi e é exatamente a presença chinesa que dinamizou a saúde da economia mundial e africana em particular, através da demanda de matérias-primas e de injeção de bilhões de dólares norte-americanos no mercado financeiro internacional.

\section{Contexto da Cooperação Moçambique-China e a Dependência de Trajetória}

6 A histórica cooperação Moçambique - China, se enquadrada no contexto da busca pelo Moçambique de alternativas de emancipação política face à colonização portuguesa. A recusa do Ocidente em dar apoio em material bélico durante a Luta de Libertação Nacional (1964 - 1974) e guerra civil (1976 - 1992) empurrou Moçambique a se alinhar ao bloco socialista, no qual encontrou todo o apoio necessário (material bélico, combustível e bens de consumo) até a independência em 1975 e depois. É no contexto do cruzamento entre conflito, miséria e solidariedade com vista à emancipação política, econômica e social que devem ser enquadradas as relações de amizade e cooperação entre Moçambique e China em particular, e com os demais países tanto da antiga URSS assim como ocidentais, latino-americanos, entre outros países.

China foi o primeiro país a estabelecer relações diplomáticas com Moçambique independente, a 25 de Junho de 1975 - dia da independência nacional. A partir de então, vários acordos foram assinados entre os dois países, no contexto da perspectiva chinesa de win - win cooperation, em particular no domínio da saúde, agricultura e defesa. De acordo com Chichava (2010, p. 338) em 1976, os acordos na área de saúde, previam o envio a Moçambique, em cada dois anos, de 12 profissionais de saúde ao hospital de Maputo e em 1977, China estabeleceu grandes machambas ${ }^{1}$ estatais, em Moamba - província de Maputo, Sul de Moçambique. Apesar de a China ter sido o primeiro país a estabelecer 
relações diplomáticas com Moçambique, tais relações não avançaram muito numa primeira fase. Jackson (1995) (apud Chichava, 2010) aponta cinco fatores que fundamentaram as clivagens entre os dois países: i) disparidade de apoio à guerra civil em Angola, enquanto Moçambique apoiava o Movimento Popular de Libertação de Angola (MPLA) a China apoiava União Nacional para Independência Total de Angola (UNITA); ii) a declaração em 1977 de Moçambique ser "marxista-leninista" com mais inclinação para bloco soviético do que o lado chinês, embora Moçambique tenha procurado sempre equilíbrio para não ser vinculado nem a Moscovo e nem a Pequim; iii) a condenação da Frente de Libertação de Moçambique (FRELIMO) ${ }^{2}$ da invasão chinesa ao Vietnam; iv) o apoio chinês ao regime cambodjano Pol Pot em 1979, e; v) o fato de Moçambique, junto com Angola e Etiópia não ter condenado a invasão soviética ao Afeganistão, votando contra a resolução das Nações Unidas que condenava tal invasão. Como conseqüência deste último incidente,

o embaixador chinês em Moçambique - Yang Shouzeng deixou o país na companhia da equipa médica chinesa em 1980, como protesto, tendo regressado a Moçambique em 1981. Todavia, apesar do regresso do embaixador com a sua equipa médica e das visitas de Joaquim Alberto Chissano (1982) e Samora Machel (1984), ex-Ministro dos Negócios Estrangeiros e ex-presidente de Moçambique, respectivamente, nenhuma alta autoridade chinesa visitou Moçambique, fato que só veria acontecer em 1987, com a visita do então conselheiro do Estado e Ministro dos Negócios Estrangeiros, Wu Xuequian. Depois foi a vez do também então ministro dos Negócios Estrangeiros Qian Qichen visitar Moçambique em Agosto de 1988, tendo na altura assinado um pacote de ajuda avaliado em 12 milhões de dólares americanos (CHICHAVA, 2010, $340)^{3}$.

O autor continua apontando que a normalização das relações entre Moçambique e China deve ser enquadrada à crise econômica e política do regime de Maputo devido ao colapso do seu projeto socialista e os efeitos da guerra civil. Tal situação obrigou Moçambique a normalizar relações com outros países, em particular com a África do Sul - país com o qual as relações eram sempre de tensão devido às sabotagens econômicas perpetradas pelo regime de segregação racial - Apartheid. O Apartheid junto com o regime de Ian Smith da Rodésia do Sul (atual Zimbábue) apoiou militarmente a Resistência Nacional de Moçambique (RENAMO) ${ }^{4}$, movimento armado que conduziu a guerra civil. A crise políticomilitar e econômica financeira, sobretudo nos anos 80 lançando Moçambique às instituições da Breton Woods. É nestas instituições, Fundo Monetário Internacional (FMI) e Banco Mundial (BM), que não só Moçambique encontra apoio financeiro para atender à situação humanitária da guerra civil, como também, os dogmáticos condicionalismos capitalistas no contexto das teorias liberais que o levaram a reformas econômicas para soluções políticas. Neste sentido, é razoável aceitar que fatores históricos de cunho político-militar levaram Moçambique a uma situação de dependência externa, que se traduz em ajuda externa tanto para as despesas da luta de libertação nacional quanto para funcionamento das despesas públicas. Dito de outra forma, não foi a dependência que levou Moçambique a pedir apoio, mas sim, o inverso, ou seja, a dramática situação política de luta pela emancipação política levou o país a solicitar ajuda externa, o que o afundou numa dependência externa quase que eterna. As relações de ajuda externa, no contexto da lastimável situação política, transformaram o status quo da ajuda externa numa situação de dependência multidimensional, estrutural e dinâmica, na modalidade como descreve Castel-Branco (2011).

9 Esta dependência técnica e financeira tornou Moçambique em uma dos países altamente endividando do mundo, chegando a um estado de crise da dívida, uma situação que 
persiste até hoje. É neste contexto, que os países centrais junto aos países altamente endividados desenharam políticas que se traduziram em ajuda externa, perdão da dívida aos países altamente endividados. De acordo com Castel-Branco (2011) os objetivos do doador e do receptor coincidem, dado que ambos estão interessados em alterar uma situação tida como anormal para a melhor, ainda que suas posições e motivações sejam diferentes e por vezes conflitantes. No auge desse consenso e reconhecimento comum da necessidade de alterar a situação anormal, a África Subsaariana, por exemplo, pediu em 2005, através da Comissão Africana um aumento da ajuda externa de US\$ 25 bilhões, o que constituiu o triplo da ajuda externa do continente africano. $O$ projeto Milênio das Nações Unidas estima que a Ajuda Oficial Global para o Desenvolvimento (ODA) poderá chegar aos US\$ 195 bilhões em 2015, contra os US\$ 79 bilhões em 2004 (NOVUNGA, 2008, p. 38). Confirma este dado o relatório do Grupo do Banco Africano do Desenvolvimento (GBAfD) e Organização para Cooperação Econômica e Desenvolvimento (OCED) ao apontar que em 2014 os fluxos externos para África registraram um crescimento recorde de 200 bilhões de dólares, um montante de cerca de quatro vezes superior ao registrado em 2000. A ajuda externa foi desenhada pelas Nações Unidas no sistema das relações internacionais, como uma política de curto prazo, virada para a reconstrução pós-guerra. Contudo, evidências empíricas apresentados por Brautigam (2000) apontam que cerca de 30 países recebem ajuda externa há mais de três décadas e estima em mais de $10 \%$ do Produto Interno Bruto (PIB), sobretudo na África Subsaariana com exceção da África do Sul.

10 Sustentam esta visão de Brautigam (2000) os dados apresentados pelo relatório do GBAfD e da OCED de 2008 e 2015 sobre o fluxo tanto da Assistência Pública ao Desenvolvimento (APD), Ajuda Oficial Global para o Desenvolvimento (ODA) quanto sobre o IDE e as remessas da diáspora africana. Em termos do fluxo do Investimento Direto Estrangeiro (IDE) o GBAfD e OCED (2008, p. 20) apontam que este tem vindo a crescer desde 2002 quando atingiu 36 bilhões de dólares em 2006, o que significou um aumento de $20 \%$ relativamente a 2005 e o dobro do valor em comparação com 2004. O relatório continua mostrando que em 2006, um total de 23 mil milhões de dólares foram destinados para o Norte de África e os restantes US\$12 mil milhões para a África Subsaariana. O aumento do IDE é associado pelo relatório à subida do preço de matérias-primas, fato que é para este artigo uma conseqüência da demanda de matérias-primas pelos países asiáticos, principalmente a China. Esta procura conforme mostra o relatório aumentou o boom de investimentos na indústria extrativa, para além do aumento de fusões e aquisições (F\&A) na banca e na indústria de telecomunicações, conjugado com os esforços dos governos de liberalização dos mercados e privatizações das empresas públicas.

11 Se até 2006, Moçambique não integrava a lista dos principais destinos do IDE como mostra o relatório do GBAfD e OCED de 2008, este passa a ser preferência dos investidores após 2006. De acordo com o mesmo relatório, "o IDE aumentou em 33 países africanos e diminuiu em 21, sendo os destinos de topo em 2006, o Egito (US\$ 10 mil milhões), a Nigéria (US\$ 5.4 mil milhões) e o Sudão (US\$ 3.5 mil milhões), seguidos pela Tunísia, Marrocos e Argélia". Já no seu relatório de 2015, o GBAfD e a OCED mostram um aumento do IDE de cerca de $60 \%$ de 2002 a 2014, ao situou-se nos 60.4 bilhões de dólares, face aos 36 bilhões de 2002. Neste período de 2014 a Nigéria não só se manteve na lista dos principais destinos do IDE, como também registrou um aumento de 1.1 mil milhão no seu investimento, ao alcançar a cifra de US\$ 6.5 mil milhões. Marrocos com um investimento de US\$ 4.8 mil milhões colocou-se na segunda posição, seguido pela África do Sul com US\$ 4.8 mil milhões e Moçambique com US\$ 4.1 mil milhões. 
12 As disparidades no fluxo do IDE entre país e regiões são explicadas pelo relatório do GBAfD e OCED (2015) como conseqüência de dois fatores: a dotação de recursos naturais e o risco político. Mas a questão de instabilidade política é problemática considerando o fluxo do IDE para o Sudão, um país com tremendos problemas políticos. O mesmo pode ser dito para o caso de Moçambique que a partir de 2013 tem apresentado sinais de instabilidade política ao mesmo tempo em que dispara o IDE. Não obstante estes focos localizados de instabilidade política em alguns países africanos, o Norte de África mostrou-se o maior destino do IDE do que qualquer outra região de África, sendo as principais áreas de investimentos a agricultura, comunicações, construção, indústria transformadora e turismo. De acordo com o relatório em referência, a Nigéria absorveu $80 \%$ do investimento direto da África Ocidental, sobretudo para a área do petróleo. A África Central e Ocidental registraram aumento no setor da indústria extrativa. $\mathrm{Na}$ África Austral, Angola e África do Sul foram os destinos de preferência dos investidores. Todavia, nos dois países o saldo líquido do IDE foi negativo, isto é explicado pelo relatório em referência, como conseqüente da venda das ações de algumas empresas extrativas a investidores domésticos, tal é o caso dos ativos da Vodafone, dos empreendimentos imobiliários da Istithmar na África do Sul e para o caso angolano a Sonangol comprou os ativos detidos pela empresa estrangeira do ramo petrolífero.

Para além do IDE, o relatório GBAfD e OCED (2015) apresenta outras duas principais fontes de fluxo financeiro estrangeiro em África: as remessas da diáspora africana e a Assistência Pública ao Desenvolvimento (APD). Enquanto as remessas aumentaram mais de 10\%, ao alcançar US\$ 67.1 mil milhões a APD registrou uma redução, pois foi estimada pelo relatório em 55.2 mil milhões de dólares, um valor ligeiramente inferior aos $55.8 \mathrm{mil}$ milhões registrados em 2013. Tanto para o relatório do GBAfD e OCED (2015), quanto para Southall and Merlber (2009) e Brautingam (2009), existe uma tendência desde os anos 2000 de diminuição do fluxo de ajuda externa em África, não obstante as fontes reconhecerem que ela continua alta quando comparada com outros continentes.

Como se pode notar, Moçambique acompanha com maior satisfação o fluxo de capitais estrangeiros em África sendo um dos grandes receptores tanto dos IDE (sobretudo em 2014 quando se posicionou em quarto lugar ao nível do continente), assim como é um dos grandes receptores da ajuda externa. De acordo com o Banco Mundial (2005), Moçambique recebeu mais do que o dobro da média da África Subsaariana que é cerca de US\$ 26 per capita. A fonte indica que Moçambique passou de cerca de US\$ 360 milhões em 1985 para cerca de US $\$ 1.1$ bilhões no projeto de reconstrução pós-guerra até 1996. Como resultado, e de acordo com a fonte, o país conseguiu ultrapassar em termos de infraestruturas, os níveis de infra-estruturas do período antes da guerra civil. Constituiu um ambiente institucional próprio, nascimento ativo da sociedade civil e baixo índice de desemprego ${ }^{5}$. Castel-Branco (2011, p. 3) ao problematizar estes resultados coloca uma questão substancial ao questionar "como pode a contínua dependência multidimensional, estrutural e dinâmica de ajuda externa ser consistente com o sucesso"? Mas por outro lado, existe um questionamento sobre a sustentabilidade da ajuda externa porque em alguns casos, alimenta a dependência - tal é o caso de Moçambique. Ajuda externa, definida como sendo Brautigam (2000) a situação na qual o país não pode realizar muitas das suas funções de governação, tais como: provisão de serviços públicos, sem assistência técnica e financeira [...] e/ou [...] "o estado da mente onde os receptores da ajuda externa perdem as suas capacidades de pensarem para si próprios e desse modo perdem controle de si mesma..." (SOBHAN, 1996, p. 122). 
Para sustentar os posicionamentos de estado de dependência em que se encontra Moçambique Castel-Branco e Ossemane (2010) indicam que a dependência externa tem várias dimensões inter-relacionadas, podendo ser científica, tecnológica e técnica, institucional, política, econômica e financeira. Apesar de este texto reconhecer que Moçambique é profundamente dependente em todas estas dimensões, como afirma Castel-Branco e Ossemane interessa ressaltar o dado apresentado por estes autores de que $43 \%$ do investimento privado provêm do investimento direto estrangeiro (IDE) e cerca de dois terços dos empréstimos provêm da banca internacional. Os autores continuam mostrando que de 1990 a 2004, $80 \%$ do investimento total dependia de fluxo externo de capitais privados (IDE e empréstimos). De 2005 a 2010 o percentual alocado para financiar a despesa pública variou entre $85 \%$ a 91\%, o que significa entre US\$ 750 milhões em 2004 a US\$ 1100 milhões em 2008, ajuda fornecida pelo Grupo dos 19 (G 19) países da Organização para Cooperação Econômica e Desenvolvimento (OCDE). Isto significa, de acordo com Castel-Branco e Ossemane (2010) que neste período a ajuda externa financiou $50 \%$ das despesas públicas. Os autores continuam apontando que ajuda oficial ao desenvolvimento correspondeu a $22 \%$ do PIB, valor este que é cinco vezes superior à média dos países da África Subsaariana, colocando Moçambique na $11^{\mathrm{a}}$ posição dos países mais dependente da ajuda externa no mundo, cuja dívida externa é de $40 \%$ do PIB.

Os dados apresentados nos parágrafos imediatamente anteriores a este sobre o fluxo de capitais estrangeiros em África em geral e Moçambique em particular servem numa primeira fase, para demonstrar que o crescente alargamento da presença chinesa em África em geral e Moçambique em particular, não altera a manutenção e crescimento das principais fontes de divisas em África, com destaque para Ajuda Pública ao Desenvolvimento, Ajuda Oficial Global para o Desenvolvimento (ODA), o IDE e as remessas da diáspora africana. Pelo contrário, ao mesmo tempo em que os novos atores de cooperação internacional, em particular os países asiáticos e o Brasil aumentam os seus investimentos diretos e ajuda técnica e financeira em África, o fluxo dos tradicionais capitais estrangeiros, embora registre uma relativa retração que pode ser associada a crise financeira, ela continua maior. Na segunda parte deste artigo é retomada esta questão com recurso aos dados sobre o crescimento econômico e desenvolvimento de África em geral e de Moçambique em particular, o que sustenta cada vez mais a hipótese da ausência de uma relação causal entre presença chinesa e pobreza africana, pelo contrário, China foi e é o motor central desse desenvolvimento.

Apesar deste fluxo de ajuda externa, do IDE e das remessas da diáspora africana a pobreza extrema ainda continua a dilacerar a maioria da população africana em geral e da África Subsaariana em particular, o que levanta questionamentos infinitos. Por exemplo, como explicar a persistência da pobreza absoluta em África no período anterior à emergência da China, caracterizado, não só pela dolarização bilionária do continente, mas também por profissionais altamente qualificados com ambiente e arranjo institucional de ponta? Por que é que a pobreza é extrema na África Subsaariana do que qualquer outra região do mundo com um passado histórico (colonização, guerra civil) quase semelhante? Como explicar, por exemplo, a pobreza absoluta e a dependência externa de Moçambique após quatro décadas de independência caracterizadas pelo fluxo massivo de donativos e assistência técnica e financeira? Não é novidade para ninguém que a região África Subsaariana concentra mais indicadores de privação humana mais do que a sua análoga do sul da Ásia, as duas regiões do mundo com indicadores desoladores. Breves dados comparativos apresentados por Drèze e Sen $(2015$, p. 63$)$ consideram a maioria dos países 
do sul asiáticos como os que possuem baixos índices de desenvolvimento humano do que os países da África Subsaariana. Todavia, e de acordo com os autores, a renda per capita é $50 \%$ maior no sul da Ásia do que na África Subsaariana. Quanto à esperança de vida e mortalidade infantil é dez e duas vezes maior, respectivamente no sul da Ásia que África Subsaariana. A lista dos dados lastimáveis é enorme e como o objetivo deste artigo não é uma análise comparativa, talvez a pergunta que fica ao ar não deve focalizar tanto as causas da pobreza, mas como sair desta penúria considerando a dependência de trajetória? A busca de alternativas para sair da míngua é o procedimento ideal seguido pelos autores da teoria da dependência para o caso dos problemas da América Latina. $\mathrm{O}$ enfoque desta teoria de acordo com Dos Santos (2015) não é necessariamente a busca das causas da dependência, que é produto histórico da colonização e do capitalismo selvagem (cujo topo é a transfiguração de todo o valor de uso em valor de troca em Marx), mas sim, buscavam explicar as novas características do desenvolvimento socioeconômico da América Latina no período entre 1930 - 1945. Para eles o desenvolvimento e o subdesenvolvimento são aspectos diferentes do mesmo processo, assim, não é possível no contexto global, gerar-se o desenvolvimento de uns sem que isso ocorra em paralelo com o subdesenvolvimento de outros. Isto não é uma desculpa para explicar o fracasso econômico dos países subdesenvolvidos, mas uma realidade historicamente evidente. Todavia, para Castel-Branco (2011) a dependência de ajuda externa é uma anomalia que deve ser combatida ou eliminada. Sobre os fatores que explicam a dependência externa de Moçambique, Castel-Branco e Ossemane (2010) acreditam na existência de vários, de entre os quais, destacam razões históricas de economia política e de política econômica. Adicionalmente, as classes capitalistas nacionais são historicamente recentes; acesso ao erário público por vias de ligações políticas; perspectiva e iniciativas de desenvolvimento desenhadas num contexto de liberalização econômica, por uma classe inexperiente, mas também, tais políticas se apresentaram como imposição na medida em que apenas por via da liberalização e privatização, Moçambique teve acesso ao financiamento externo das instituições da Breton Woods. Neste sentido, para Castel-Branco e Ossemane (2010) os então 'emergentes capitalistas nacionais não tinham nenhuma experiência de organização da produção, da logística produtiva e das finanças à escala industrial' ${ }^{\text {. }}$. Este artigo enfatiza as razões históricas e políticas de colonização e os 16 anos de terrível conflito armado para além do assistencialismo retardatário como as causas que explicam a orquestrada dependência externa de Moçambique. Isto porque foi exatamente o contexto colonial seguido da guerra civil que não só fragilizou política, econômica e socialmente Moçambique, como também, permitiu aceder ao endividamento externo. Tal acesso ao endividamento externo aconteceu numa altura em que estava em alta a busca pelos aliados no contexto da Guerra Fria e por isso, a ajuda externa a Moçambique com forte endividamento, não só manteria o país preso à ideologia capitalista, como também, facilitaria o neocolonialismo no âmbito neoliberal de acesso fácil à dilapidação dos recursos naturais pelos países centrais.

O trajeto histórico político-militar de Moçambique é quase semelhante ao da Angola (independência em 1975 e seguida de terríveis guerras civis), como explicar a dramática situação moçambicana considerando o passado histórico? Malaui e Singapura, por exemplo, ambos foram colônias britânicas e alcançaram independência em 1964, mas em termos de crescimento econômico e desenvolvimento social, os dois países apresentam situações extremamente distintas. Isto é, penúria no Malaui e desenvolvimento em Singapura. Estas são questões que fogem o escopo deste artigo na medida em que este não é um estudo comparativo, e adicionalmente, nenhuma destas questões comparativas 
captura as verdades explicativas, dado que semelhanças do passado histórico são elementos que permitem ponto de partida para análise, porém, com insuficiências explicativas para entender tais diferenças. Tomando o caso moçambicano em relação ao angolano é comum, e com razão, invocar o petróleo e diamantes angolanos para impedir a comparação, como se o maior produtor e exportador de petróleo a Venezuela fosse um país desenvolvido via recursos naturais e o mesmo dir-se-ia relativamente à República Democrática de Congo. Ou seja, a estrutura econômica e política interna e o ambiente externo são fatores importantes para explicar o desenvolvimento e não apenas a abundância de recursos naturais. Singapura por exemplo é um dos países sem recursos naturais de alto valor econômico no mercado internacional, importando até água e sua população é produto de imigração, mas a contribuição turismo em $80 \%$ do PIB permite ao país criar condições de bem-estar para a sua sociedade. No entanto, muitos dos países africanos são verdadeiros depósitos de maiores recursos naturais, que acabam amaldiçoando suas populações - ao serem catalisadores de interesses externos gerando conflitos internos. A história econômica mundial não apresentar evidências históricas de países que se desenvolveram na conjugação da seguinte trilogia de fatores: colonização seguida de orquestrada terrível guerra civil; crise da dívida externa num contexto de total exclusão econômica e pilhagem contínua de recursos pelas grandes potências e misterioso e retardatário assistencialismo técnico e financeiro. Deste modo, a associação destes fatores constitui um dos pontos de partida para analisar o crônico subdesenvolvimento africano, do que enterrar a história para fundamentar a pobreza absoluta e dependência externa com base nos fatores conseqüentes e não pelas causas primeiras, como ensina Aristóteles.

Brautingam (2009), por exemplo, analisando as razões de pobreza em África (e no contexto deste estudo de Moçambique em particular) a partir dos fatores conseqüente defende que as causas da pobreza são complexas. "Navegando em águas turvas" o autor afirma que há três décadas era comum ouvir as blasfêmias que associavam a extrema pobreza africana com a colonização. Para fundamentar o seu argumento, o autor mostra que o sucesso econômico e político das antigas colônias, britânica e francesa - Botsuana e Maurícias, respectivamente, desautoriza o recurso à colonização para explicar as causas da extrema pobreza africana. O mesmo autor, no seu fabuloso livro intitulado "The Dragon's Gift: The Real Story of China in Africa" desprestigia a teoria do institucionalismo histórico que defende a contingência histórica e a dependência de trajetória para explicar a atual extrema pobreza que afligir África em geral e no contexto deste estudo, de Moçambique em particular, um fator determinante que para este artigo, não deve ser ignorado a curto e médio prazo. De acordo com Menicucci (2007, p. 49)

"o novo institucionalismo histórico procura explicar as diferenças entre países a partir de variáveis institucionais de nível nacional, apontando como a configuração institucional modela as interações e as estratégias políticas e estrutura as relações de poder entre grupos, gerando trajetórias nacionais diferentes".

Deste modo, é lícito afirmar que, primeiro, os dois países apontados (Botsuana e Maurícias) por Brautingam (2009) não apresentam nenhuma situação de robustez econômica capaz de serem consideradas economias modelos, apesar dos avanços relativos, como mostra o relatório econômico da Outlook (2012 e 2014). Botsuana conseguiu em três décadas sair dos países mais pobres após independência em 1966, para um país de classe média com um crescimento econômico de 4.8\% e 6.7\% entre 2012 e 2013, respectivamente e sem dívida pública externa. Os grandes desafios regularmente apontados para este país são desemprego de $17.6 \%$, pobreza de $20.7 \%$ e desigualdades 
sociais. Maurícias registra também sucessos relativos, com um crescimento econômico que se situou em 3.4\% e 3.3\% em 2012 e 2013, respectivamente. É uma das economias mais competitiva da África Subsaariana com um dos melhores ambientes de negócios da região, apesar de enormes desafios na qualidade do capital humano. Apesar do otimismo de Brautingam (2009) sobre estas economias, os relatórios do GBAfD e OCED de 2008 e 2015 não fazem destaque de relevo sobre estes países, pelo contrário, Moçambique que é tido como um dos países de fracasso econômico conseguiu liderar a atração de IDE ao lado da África do Sul, para além do rápido crescimento econômico que este país registra a nível regional.

Os dados macroeconômicos, sociais e políticos destes países mostram um desempenho considerável quando comparado com os demais países da região, no entanto não fazem destes países economias modelos. As únicas economias africanas robustas são a sul africana e a nigeriana ${ }^{7}$. Pelo fato de África do Sul ser um player africano, interessa algumas notas breves neste estudo sobre a histórica robustez da economia sul africana que não é produto do desempenho econômico do período pós o sistema de segregação racial Apartheid, mas sim, de uma conjuntura histórica de desenvolvimento econômico desde a era colonial. Tal vigor econômica alicerçada no passado histórico não sofreu grandes alterações mesmo após o fim do Apartheid dado que as minas de ouro de África do Sul não foram nacionalizadas e muito menos foram retirados os seus proprietários. Ou melhor, mudanças políticas que ocorreram na África do Sul em 1994, não se traduziram em rupturas e grandes transformações econômicas. Atesta esta idéia o estudo de Rocha (2009) ao aponta que o desempenho da economia sul africana arrasta desde os anos 80 os problemas de boicote econômico associados à política de segregação racial. Assim, de 1980 a 1993 o crescimento econômico do gigante africano foi em média negativo de 1\%. Apesar de o país ter implementado políticas reconciliatórias desde 1994, compreendendo quatro períodos, a cortina de ferro entre negros e brancos continua presente. De acordo com Rocha (2009, p. 39) a primeira geração de políticas públicas que ocupa o período de 1980 a 1993 tem como foco a legislação de segregação racial. O segundo período 1994 a 1995 está baseado do programas de reconstrução e desenvolvimento - transição democrática, com dois objetivos principais: i) criação de emprego, e; ii) redução da pobreza, aumento dos salários e redução das desigualdades sociais. Estes objetivos eram suportados por verbas que acendiam a R 2.5 bilhões nos dois primeiros anos, mas com previsão de chegar a $R$ 12.5 bilhões em 1998. O terceiro período compreende os anos 1996 a 2003, cujo enfoque é o crescimento econômico, emprego e redistribuição. Apesar de este programa ser complementar do segundo, ele marca o abandono do enfoque de políticas de redução das desigualdades e introdução do controle do déficit público e inflação. Finalmente o quarto período compreende 2004 e 2010 tem como centro acelerar ações e iniciativas para o crescimento econômico da África do Sul - crescimento compartilhado. Não obstante estes programas, o Rocha faz perceber que o crescimento econômico da África do Sul quando comparado com outras economias emergentes, não só é baixo, como também, a inclusão econômica desejada ainda não ocorreu. A cortina de ferro entre a maioria pobre negra e a minoria rica branca persiste para além dos problemas de escassez de eletricidade, greves na indústria mineira, criminalidade, corrupção, ou seja, são problemas econômicos que se traduzem em desafios sociais como é o caso da xenofobia.

Retomando o debate anterior, convém dizer que para, além disso, a comparação que Brautingam (2009) faz, tomando Botsuana e Maurícias como modelo desqualifica totalmente o trajeto histórico político-militar, ou seja, de luta de libertação nacional e 
guerra civil. Estes dois países não passaram por este trajeto determinista e sendo, assim, após independência iniciaram imediatamente implementar políticas de desenvolvimento econômico. Fato que não caracteriza a maioria dos países africanos dilacerados ou por guerras civis ou por perenes conflitos e golpes de Estado. Destarte, não é possível pensar e engendrar o desenvolvimento num contexto de conflito, como acontece, por exemplo, no Sudão do Sul, Somália, República Democrática do Congo, no Yémen, no Iraque, na Síri, na Líbia ou para o caso Moçambicano de guerra civil até 1992, cujo término herda uma dramática crise da dívida e uma situação de multinacionais que não pagam imposto ao Estado. Adicionalmente, o isolamento econômico de África não só impede o crescimento e desenvolvimento socioeconômico, como também, marginaliza este continente para permitir a continuação do processo colonial de pilhagem de recursos naturais - no contexto neoliberal. Após a independência as potencias imperialistas ocidentais mantiveram seu domínio sobre África, mas noutras modalidades, cujo destaque no contexto deste estudo vai para políticas assistencialistas de ajuda externa caracterizadas por forte presença das Organizações Não-Governamentais Estrangeiras, Ongs e outras formas de controle das políticas dos Estados - este é o primeiro ponto para explicar a dependência de trajetória. $\mathrm{O}$ segundo ponto de destaque no contexto deste estudo para explicar a dependência externa, no contexto Moçambicano é o ambiente e o arranjo institucional incapaz de desenvolver instituições jurídicas fortes capazes de criar um Estado de Direito, com clara separação de poderes entre o legislativo, o judiciário e o executivo, apesar de a Constituição de 1990, ter introduzidos estes parâmetros. Apesar de o artigo 134 da Constituição da República de Moçambique consagrar a separação do poder entre os órgãos de soberania ${ }^{8}$, sob ponto de vista prático tal separação não é efetiva, gerando um ambiente e arranjo institucional ruim. Neste contexto, não existe, por exemplo, uma plena democracia substantiva, Pedone (1986) e as eleições têm apenas o formalismo democrático, ou seja, se esgota em eleições periódicas, dotações orçamentais e gastos públicos [...], sem que isso se traduza em valores como justiça, igualdade, liberdade e bem-estar.

Sobre o primeiro fator, interessa afirmar que tanto Southall and Merlber (2009) e Brautingam (2009), assim como, Francisco (2010) e Homerin (2005) apresentam dados sobre forte presença das ONG's em África em geral e em Moçambique em particular. De acordo com Franscico (2010) entre 1994 e 2003 existiam em Moçambique 99 ONG's estrangeiras, num universo de 4.217, sejam elas nacionais ou estrangeiras, mas ambas sem fins lucrativas. Na mesma perspectiva, o estudo realizado pela embaixada da França em Moçambique, cuja redação esteve a cargo de Homerin (2005) cita o Instituto Nacional de Estatística (INE) apontando que em 2004 haviam, só na capital Maputo, 758 instituições sem fins lucrativas ${ }^{9}$, empregando cerca de 4.200 pessoas, contra 605 instituições da administração pública presentes na capital Maputo. A partir do informe de 2008 da Direção Provincial de Saúde de Tete sobre as atividades das 11 ONG's que operam apenas na província de Tete, centro de Moçambique é possível notar que as principais áreas de atuação são: saúde, educação, alimentação e cuidados domiciliários, entre outras, ao passo que as multinacionais operam no ramo extrativo de minerais. Em termos gerais Moçambique é o extremo de confluência de quase todas as organizações estrangeiras. ${ }^{10}$ Uma das características dessas ONG's é ter funcionários estrangeiros altamente qualificados, salários robustos ${ }^{11}$, poder financeiro formidável e ambiente e arranjo institucional com forte capacidade de implementação de programas e projetos sucedidos. E como foi discutido nas páginas 4 a 9 deste estudo, Moçambique é também a confluência 
de fluxo de donativos e investimentos quando comparado com os seus vizinhos. E como mostram Brautingam (2009) e Southall and Merlber (2009) os programas assistencialistas incluem, entre várias coisas, rigorosos e periódicas reuniões de avaliações, conferências, debates científicos, pesquisas, workshops, treinamento entre outras formas de garantia da racionalidade, eficiência e eficácia das políticas públicas e programas. A pergunta mais difícil de responder está associada ao feedback, ou seja, por que é que a miséria persiste? Há quem poderá argumentar, e com razão, que o desenvolvimento não é produto exclusivo destas organizações, mas sim, da conjugação do tripé: Estado, setor privado e organismos e ambiente internacional. De fato, mas interessa como já foi sintetizado neste artigo que a construção da capacidade institucional em Moçambique ocorre com forte assistência técnica e financeira dos países centrais, países com larga experiência e principalmente no contexto da adesão a Breton Woods em 1984 e nas políticas de democratização dos anos 90.0 que é que falhou considerando este ambiente? Embora esta pergunta é indiretamente ${ }^{12}$ discutida na segunda parte deste trabalho, duas notas podem ser brevemente colocadas. Primeiro breve exame do ambiente e arranjo institucional criado e/ou em construção em Moçambique. Tal fragilidade do ambiente e arranjo institucional é associado, neste estudo, como um dos fatores determinantes do feedback negativo. Segundo a presença dessas ONG's não tem por objetivo maximizar os interesses nacionais em primeiro plano, mas, sobretudo dos seus países, afinal de contas cooperação está no plano de interesses dos Estados e não no que o Brasil chama de cooperação solidária ou benefícios mútuos como prevê a política externa indiana.

Começando pelo segundo ponto, convém fazer algumas citações bem breves a Boron que melhor captura o contexto e o padrão de cooperação entre centro e periferia. Para Boron (2002, p. 90) existe um duplo padrão pelo qual os EUA julgam os governos e suas ações:

Um padrão é utilizado para avaliar a soberania dos amigos e aliados dos Estados Unidos; outro bem diferente é o que se usa para julgar a dos neutros ou dos inimigos. A soberania nacional dos primeiros deve ser preservada e fortalecida, a dos segundos vede ser enfraquecida e violada sem qualquer tipo de escrúpulos ou falsos problemas de consciência.

Esta citação apesar de fazer menção aos EUA, ela parece uma política geral de todos os países centrais, mas com variadas modalidades. É sobejamente conhecida a queda de todos os governos dos países periféricos que não seguem as orientações dos países centrais. A Líbia, o Iraque, o isolamento econômico de Cuba, do Zimbábue, entre outros Estados mostra claramente este comportamento de imposição para que todos os Estados sejam aliados. A partir desta noção as ONG's passeiam à sua classe fazendo tudo quanto mandam seus governos centrais. Os governos dos países periféricos, como afirmam Mandela e Mbeki citados por Bond (2005, p.239) que "não é bom permanecer em tensão com uma grande potência" não só nada fazem, como também, não têm poder de nada fazer. Disto é razoável afirmar que a dolarização bilionária de Moçambique, não tem em vista cumprir interesses do país, mas sim, dos países de origem dessas ONG's e o governo moçambicano, numa estratégia de sobrevivência, aprendeu a lição de Mandela e Mbeki de não permanecer em tensão com as grandes potências. 0 resultado dessa estratégia de sobrevivência é claramente explicitado por Boron (2002) ao citar o historiador hondurenho Ramón Oquelí, afirmando que

A importância das eleições presidenciais com ou sem fraude, é relativa. As decisões que afetam Honduras são tomadas primeiro em Washington, a seguir, no comando militar norte-americano no Panamá (o Southern Command), depois, no comando da base norte-americana em Palmerola, aqui em Honduras; em seguida, a embaixada 
norte-americana em Tegucigalpa; em quinto lugar, vem o chefe das forças armadas hondurenhas, e, apenas em sexto lugar, aparece o Presidente da República. Votamos pós em um funcionário de sexta categoria, quanto ao poder de decisão. As funções do presidente se limitam à administração da miséria e à obtenção de empréstimos norte-americanos (BORON, 2002, p. 98).

Infelizmente esta é também a função dos presidentes africanos, ou seja, a de administrar miséria e empréstimos norte-americanos e/ou dos países centrais. As ONG's e atualmente com as multinacionais em Moçambique ditam as regras de jogo e fazem tudo quanto querem. Essa liberdade é associada à fragilidade do ambiente e arranjo institucional, como a seguir se analisa no primeiro ponto sobre ambiente e arranjo institucional neste trabalho.

Quanto ao primeiro ponto, Menicucci $(2007$, p. 49) ao discutir o instittucionalismo histórico aponta que

a maioria dos estudos que enfatiza os constrangimentos institucionais centra-se nas instituições governamentais formais e nas organizações políticas, [...] dado que as políticas públicas levam à constituição de instituições e com efeitos estruturais, na medida em que colocam constrangimentos ao comportamento dos atores políticos e às decisões que podem ser tomadas relativamente a bens públicos, ou seja, para elaboração ou reforma de políticas públicas.

Por sua vez, Arthur (1990) no seu texto sobre positive feedback no contexto econômico, indica que pequenas mudanças incrementais geram competitividade e mutações positivas tanto na economia quanto nas instituições. Por seu turno, North (1991) assinala que tais mudanças incrementais conectam o passado com o presente e o futuro. $O$ autor continua anotando que a evolução histórica das instituições na qual o performance histórica é entendida como parte da estória institucional. Este posicionamento conjugado com o parágrafo anterior neste estudo citando Menicucci (2007) autoriza a validade do argumento de que não dá para dissociar o atraso econômico e social de Moçambique ao seu passado histórico, a curto e médio prazo. Esta colocação não encontra o mesmo apoio por parte da maioria da literatura nacional e internacional e David (1994) mostra que existem teorias institucionais que indicam que para compreender o desempenho das instituições é melhor não recorrer ao seu passado, mas sim, ao presente e ao futuro. Isto por que os arranjos institucionais são sempre elásticos e adaptativos às novas realidades de modo a alcançar a eficiência necessária. De fato, mas esta é característica das instituições privadas e públicas com alto grau de capacidade institucional e não o caso dos países pobres em geral (salvo algumas exceções) e de Moçambique em particular, nas quais o que gera dinamismo e mudanças é a tecnologia absoluta dos países centrais. Ao analisar o ambiente e os arranjos institucionais no contexto moçambicano é fácil perceber esta postura.

O conceito de ambiente e arranjos institucionais dado por Gomide e Pires (2014) permite entender como ambiente institucional, as diretrizes políticas, econômicas e jurídicas que orientam de forma geral, a institucionalização e funcionamento das instituições. Ao passo que arranjos institucionais estão associados ao conjunto de regras, mecanismos e processos que definem a forma particular de coordenação de atores e interesses na implementação de cada política. No contexto moçambicano, a mudança do ambiente institucional, foi dada pela Constituição de 1990 que introduziu o Estado de Direito Democrático, alicerçado na separação e interdependência de poderes e no pluralismo, liberdade de expressão, de organização partidária, das associações e no respeito e 
garantia dos direitos e liberdades fundamentais dos cidadãos. Para já não citar as profundas mudanças econômicas operadas nos anos 80 .

31 Como resultado destas mudanças e da liberalização e forte abertura econômica ao capital estrangeiro foram criados três sistemas institucionais na formulação de políticas públicas, nomeadamente: o representativo (partidos e seus eleitos), o participativo (sociedade civil, espaço de consultas públicas) e o de controle burocrático (accountability horizontal, parlamento, judiciário e o executivo). É neste âmbito que se insere a maioria das ONG's e este ambiente institucional devia permitir o pluralismo no processo decisório e contribuir não apenas para a qualidade das decisões, mas também a sua efetiva legitimidade. Isto por que para Lijphart (1999) apud Gomide e Pires (2014, p. 18) "políticas apoiadas em amplos consensos são mais propensas de serem implementadas com maior sucesso e a seguir o seu curso do que políticas impostas por um governo que toma decisões contrárias aos desejos de importantes setores da sociedade". Todavia, os mesmos autores citando o caso do leste asiático (Coréia do Sul, Taiwan e Indonésia) indicam que "países com sistemas políticos não democráticos e pouco abertos às representações de atores sociais políticos tendem a ter qualidade nas instituições estatais e nas suas relações com a elite industrial". Estes dois extremos do ambiente institucional podem levar a ilação de que o desenvolvimento socioeconômico é independente do ambiente institucional democrático. A China é o exemplo de ausência de democracia formal, mas com eficiência institucional e o Brasil, pode ser tomado como o seu oposto nas atuais economias emergentes. Este estudo embora reconhecendo a eficiência do caso chinês, sobretudo por que os modelos democráticos e plurais de formulação de políticas públicas tendem a ser exageradamente burocratizados e morosos, principalmente pela dificuldade de afirmar consenso no contexto do pluralismo de posições, opta por esta via democrática considerando que este é o modele moçambicano. Não obstante, o assistencialismo ocidental, as políticas governamentais ainda não consolidaram as bases democráticas para o pluralismo de idéias em Moçambique. Como já foi dito na página 10 deste estudo, as eleições são formais e não substantivas. $O$ resultado desse formalismo é que a maioria do eleitorado não vota políticas públicas, mas sim, o legado histórico dos partidos políticos - path dependence. Para, além disso, o acesso a cargos públicos via confiança política e não via meritocracia fragiliza os alicerces para um possível arranjo institucional. Associado a esta incapacidade estatal, convêm apontar as outras duas inépcias, isto é, o técnico administrativo e o político. 0 primeiro está associado à competência dos agentes do Estado e orientada para a produção de resultados. No atual contexto em que Moçambique é o país mais dependente de ajuda externa mesmo para educar a sua população de 24 milhões de habitantes dos quais $49.9 \%$ são analfabetos é pouco provável que se desenhe um arranjo institucional a curto e médio prazo que possa oferecer técnicos administrativos qualificados e produtores de resultados desejados. Adicionalmente, está a deplorável qualidade de ensino, cujo enfoque é a corrida ao certificado ou ao diploma pelos estudantes ou para melhorar a condição salarial ou para acesso ao emprego e não necessariamente a busca de conhecimento para ser competitivo no mercado de trabalho $\mathrm{e}$ produzir resultados. A remoção deste inequívoco, não passa apenas por um arranjo institucional no Ministério da Educação, mas, sobretudo pelo arranjo no ambiente político, ou seja, acesso competitivo ao emprego e cargos públicos via competência técnica e não filiação partidária ou esquemas corruptos ou ainda, salário em função ao desempenho e não ao grau acadêmico apenas. 
32 A segunda componente para a criação de uma capacidade do Estado está relacionado a dimensão política, ou seja, "habilidade da burocracia do executivo em expandir os canais de interlocução, negociação com diversos atores sociais, processando conflitos e prevenindo a captura dos interesses específicos" (GOMIDE e PIRES, 2014, p. 20). Dissociando esta conceptualização para o caso moçambicano pode se afirmar avanços constitucionais e por vezes, práticas relativamente ao poder político de expandir os canais de interlocução e de negociação. Embora a ditadura do voto da maioria parlamentar na Assembléia da República de Moçambique ${ }^{13}$ ainda impere, ou seja, que faz valer o princípio democrático do voto da maioria existem leis fundamentais aprovadas com estreito respeito ao pluralismo democrático de vários atores. Citando apenas dois exemplos, pode se destacar a Lei eleitoral no 30/2014, de 26 de Setembro, que foi aprovada por consenso entre a maioria parlamentar, a Frente de Libertação de Moçambique (Frelimo) e os dois partidos de oposição com acento na Assembléia da República de Moçambique: a Resistência Nacional de Moçambique (Renamo) (maior partido da oposição) e o Movimento Democrático de Moçambique (MDM). E a Lei no 29/2014, de 9 de Setembro, sobre a Acordo de Cessação das Hostilidades Militares, celebrado a 5 de setembro de 2014 entre o Presidente da República de Moçambique e o Presidente do Partido Renamo.

33 Mas o mesmo não se pode dizer quanto à parte final do conceito sobre a dimensão política, isto é, prevenir e capturar interesses específicos. o que mais impera para o arranjo institucional são os interesses específicos, sobretudo da elite política fomentando a chamada grande corrupção e protecionismo partidário. Este é o objeto de estudo de todo o trabalho que é discutido de forma profunda na segunda parte, tomando os debates, dilemas e realidades da cooperação Moçambique - China como estudo de caso. A hipótese a ser investigada procura demonstrar que não é que a China seja mau doador como defende alguma literatura, mas a dimensão política moçambicana como componente para entender a capacidade do Estado para além da sua associação a interesses particulares e partidários, é frágil para se lidar com os interesses do gigante econômico chinês, ainda que tais interesses se situem de fato no contexto de win-win cooperation, como defende a política externa chinesa. Este cenário retoma e reforça de certa forma as fragilidades estatais para negociar e afirmar contratos com benefícios avultados para Moçambique, os mesmos problemas que impediram e/ou impedem o desenvolvimento socioeconômico apesar do assistencialismo técnico e financeiro que dura mais de 40 anos com os países centrais.

\section{A Nova Era de Cooperação Moçambique - China: debates, dilemas e realidades}

34 A nova era de cooperação Moçambique - China desde os anos 2000, não só carrega consigo fervorosos debates e dilemas, como também, apresenta algumas realidades de avanças significativos em termos de ganhos para Moçambique. De acordo com Chichava (2010, p. 340 - 341) foram assinados acordos bilaterais entre os dois países, sobretudo nas áreas de defesa e segurança, educação, infra-estruturas, comércio, ciência e tecnologia. Em termos de evidências de ganhos para Moçambique - realidades, o autor destaca: a) infraestruturas: i) a construção do novo edifico do parlamento moçambicano, concluído em 2000 e que contou, também com o financiamento da Dinamarca; ii) a construção em 2003 do maior Centro de Conferências estatal - Centro de Conferência Joaquim Chissano; iii) 
construção dos ministérios dos Negócios Estrangeiros, do Turismo, da Juventude e Desporto e do extinto Ministério da Função Pública; b) defesa e segurança ${ }^{14}$ : i) construção do bairro militar, a um custo de US\$ 7 milhões; ii) assistência técnica e logística às forças armadas e à polícia (oferta de viaturas, diversos equipamentos eletrônicos, uniforme, formação, treinamento, entre outros); iii) e o programa de desminagem em 2001. Na área comercial, foram assinados, de acordo com Chichava (2010) acordos de Comércio e Promoção e Proteção Recíproca do Investimento. Criada a Comissão Mista para Economia e Comércio e uma parte da dívida moçambicana (69\%), na altura avaliada em 22 milhões foi oficialmente perdoada. Entre 2001 e 2007 o comércio bilateral atingia 280 milhões de dólares americanos, passando a China da posição $27^{\mathrm{a}}$ para $6^{\mathrm{a}}$ e desta para $2^{\mathrm{a}}$, em 2001, 2007 e 2008 (76,8 milhões de dólares americanos, correspondente a quinze projetos), respectivamente, na lista dos maiores investidores em Moçambique, liderada por África do Sul. O autor com recurso a alguns estudos, como é o caso de Reisen e Ndoye (2008) aponta que em 2006, Moçambique fazia parte da lista dos oitos países africanos ${ }^{15}$ que mais ajuda recebia da China. No mesmo período, Moçambique recebeu $80 \%$ do total dos empréstimos chineses concedidos a África. No seio dos Países de Língua Portuguesa (PALOP), Moçambique é o segundo parceiro da China, depois da Angola e o quarto na Comunidade dos Países de Língua Portuguesa (CPLP), depois do Brasil, Portugal e Angola. No campo da ciência e tecnologia, estava prevista a instalação de dois centros de investigação agrária, um em Umbeluze (2008) e outro e Moamba (2010), avaliados em US\$ 700 milhões. Chichava (2010, p. 341) continua apresentando os ganhos para Moçambique no contexto da cooperação com a China e indica que em 2007, a quando da visita a Moçambique do então Presidente Chinês Hu Jintao, os produtos moçambicanos com acesso livre ao mercado chinês passaram de 190 para 442 e o peso da China no setor da construção de obras públicas é exageradamente maior, aborrecendo os menos competitivos empreiteiros nacionais. O autor citando Emmy Boost (2008) estima que em 2008, mais de um terço, num total de 600 quilômetros de estrada tenham sido construídos por empresas chinesas. A lista das construções chinesas em Moçambique contempla a reabilitação dos sistemas de abastecimento de água, a construção do Estado Nacional em Maputo em 2010, cujo investimento é de 57 milhões de dólares americanos; a reabilitação e modernização do principal aeroporto de Moçambique, avaliado em 70 milhões de dólares e o financiamento de 2,3 bilhões de dólares americanos para a construção de uma das maiores barragens africana - Mpanda Nkuwa. Em termos de empresas chinesas em Moçambique, em 2008, havia 41 empresas empregando 11.214 moçambicanos nas áreas de agricultura, pesca, indústria e construção. Em termos da relação comercial entre Moçambique - China é possível notar nos anuários estatísticos do Instituto Nacional de Estatística (INE) de 2000 e 2013, significativas melhorias, ou seja, passou de 0,7\% para 2,6\% das exportações de Moçambique para China, em 2000 e 2013, respectivamente e aumentou o volume de importações, de 2,2\% em 1999 para 6,4\% em 2013.

Em termo de Investimento Direto Estrangeiro (IDE) de cada um dos países dos BRICS em Moçambique, China é o segundo maior investidor após África do Sul. De acordo com Jansson e Kiala (2009, p.9) e (apud Wache, 2014, p. 245) o comércio entre os dois países cresceu a olhos vivos, isto por que, se em 2008 o comércio era de 442.7 milhões de dólares, em 2012 estava na cifra de 1.224 milhões de dólares. Este crescimento de relações comerciais tornou a China no segundo maior investidor com US\$ 76.8 milhões, apenas superado pela África do Sul com US\$ 136 milhões. De acordo com Shinn (2012) (apud Wache, 2014) até 2010 o IDE chinês em Moçambique já alcançava a cifra de US\$ 607 
milhões com a compra pela Wuban Iron and Steel Corporation de 8\% das ações de Riversdale, empresa australiana com concessão para exploração de carvão mineral na província de Tete. Dados fornecidos apenas pelo Centro de Promoção de Investimentos (CPI) e o Gabinete das Zonas Econômicas de Desenvolvimento Acelerado (GAZEDA), sem contar com os investimentos chineses aprovados no Ministério dos Recursos Minerais e Energia permitem perceber que de 1990 a primeiro semestre de 2015, China tem em Moçambique 133 projetos de investimentos aprovados, gerando 26.133 mil novos empregos, num investimento de aproximadamente 2 mil milhões de dólares norte-americanos. Com base nesses dados fornecidos pelos CPI e GAZEDA é fácil notar que em termos globais, China está apenas abaixo da África do Sul em termos de IDE em Moçambique. Mas qual é o grau de significância dos ganhos para Moçambique em termos comparativos com a China? Embora importante esta pergunta mas existem vários fatores que fragilizam a possibilidade de Moçambique ganhar de forma igual que a China no contexto do win-win cooperation, como prevê a política externa chinesa, dos quais convém citar dois. Primeiro, existência em Moçambique da lei de investimentos que prevê isenções fiscais e aduaneiras, e; segundo, porque em muitos projetos resultantes de investimentos deste país asiático, China aparece com maior investidor. Deste modo, Moçambique ganha em função destes fatores e por isso não é possível uma igualdade matemática de ganhos. Outro dado aponta que a busca de resposta à pergunta anteriormente colocada não deve ser encontrada apenas nos contratos, mas, sobretudo, no exame do grau da eficácia do processo de institucionalização ocorrido a quando das mudanças econômica e política sob assistência técnica e financeira dos países ocidentais.

Apresentada a síntese de algumas realidades com evidências históricas animadoras na cooperação Moçambique - China parece dispensável discutir os debates e dilemas em redor, isto porque os fatos são visíveis a olho nu, sobretudo na capital Maputo. A pergunta que motiva a necessidade de tal debate é por que é que a China é literalmente maldiçoada mesmo considerando estes ganhos emblemáticos para Moçambique. Note-se que em termos de infra-estruturas para o governo, nenhum outro país do mundo já investiu em Moçambique à dimensão chinesa. China está operando a revolução financeira do século XXI que em termos de investimentos em todo o mundo nunca antes havia se observado na história econômica. China esteve junto com Moçambique nos momentos mais críticos das duas guerras e continua ainda hoje considerando a síntese dos ganhos ora apresentados no parágrafo imediatamente anterior a este. Para este estudo, não existe nada de errado na presença da China em África em geral, e em Moçambique em particular, que supera as desumanidades das potências centrais de colonização e neocolonização, apenas uma atitude anti-chinesa dessas potências por que passam a ter um adversário a disputar nos recursos africanos. Este argumento não toma China como "salvador" de África e muito menos pretende isentá-la de várias práticas contraproducentes, mas sim, mostrar que infelizmente África em geral e Moçambique em particular é terreno fértil de disputas das grandes potências desde a Conferência de Berlim - 1884/5. Este fato obriga a tomar por empréstimo o título da obra do historiador moçambicano Adam (2006) - "Escapar aos Dentes do Crocodilo e Cair na Boca do Leopardo" que no contexto deste artigo significa que África em geral e Moçambique em particular, estão procurando forma de se livrar da perene colonização e neocolonização, só que isso os leva a cair num outro dilema de exploração desenfreada de recursos naturais. Mas esse problema não é tomado neste artigo como tendo sua gênese no gigante econômico chinês, porque este apenas aprendeu a lição de exploração com os países centrais. São esses países que ajudaram Moçambique a construir instituições frágeis incapazes de defender interesses nacionais, o que alimenta 
atualmente esquemas de corrupção e protecionismo partidários das empresas chinesas na exploração de recursos naturais, chegando a empresa Xue Bing Huang a financiar a campanha eleitoral do maior partido no poder, como indica o CIP no seu relatório $\mathrm{n}^{\mathrm{o}}$ $11 / 2014$.

Southall and Melber (2009), Brautingam (2009) e Chichava (2010) ajudam a introduzir o debate em torno da nova era de cooperação África - China e por esta via, também de Moçambique. A questão que tanto desperta maior admiração dos especialistas e/ou interessados pelos assuntos da cooperação África - China é que nos últimos anos os investimentos chineses em África são enormes do que qualquer período desde os anos 60 . Os dados apresentados no parágrafo imediatamente anterior a este, sobre Moçambique confirmam esta realidade. Desde os anos 2000, assiste-se o crescimento da média per capita de investimento por cada um dos países africanos. De acordo com Southall and Melber (2009) o rápido crescimento econômico de muitos dos países africanos está associado ao aparecimento da China como ator econômico, ao lado de novos países emergentes como Brasil, Índia, Rússia, África do Sul, Coréia do Sul, entre outros, desafiando o ocidente como ator mais influente do continente. Os autores continuam apontando que existe um debate substancial sobre o que representa o crescimento e os investimentos chineses em África, se este inaugura uma nova e significante fase da trajetória histórica do continente ou um novo imperialismo. Essencialmente o debate centra-se sobre se o novo atropelo africano representa a competição e conflito entre as potências imperialistas em África e/ou tais investimentos representam de forma análoga o histórico processo que culminaria com a Conferência de Berlim - 1884/5. Muitos autores acreditam que se é de fato uma nova fase de imperialismo, ela se manifesta de forma informal do que formal. Associa-se a expansão da China como novo imperialista, a índia, o Brasil, assim como os investimentos da África do Sul em África. Analisando os dados do CPI e do GAZEDA no período de 1990 a primeiro semestre de 2015 é fácil notar que de fato estes países acelerando os seus investimentos em Moçambique. No período em referência, por exemplo, o Brasil investiu US\$ 761.123.293.8 milhões, em 20 projetos gerando 2.870 novos empregos e a Índia colocou no mercado moçambicano US\$ 174.917.293.5 milhões em 87 projetos gerando 17.229 novos em pregos. O maior investidor africano a África do Sul, colocou em Moçambique US\$274.444.140.288.88 mil milhões em 714 projetos aprovados, gerando 63.094 novos empregos. A questão recorrente em vários analistas está associada ao tipo de emprego que é gerado e outros ainda estão preocupados com o endividamento externo. A posição plausível do governo de Moçambique não é tanto a preocupação pelo endividamento externo, mas pela sustentabilidade dos investimentos, ou seja, como é que o capital é aplicado. A opção governamental de investir em infra-estruturas sociais e econômicas necessárias é positiva na medida em que aumenta a dinâmica da economia para além de melhorar as condições sociais. Como foi citado anteriormente, $25 \%$ da dívida pública externa é feita pelo setor privado incluindo estrangeiro. $O$ que mostra que os investidores externos que entram em Moçambique, nem todos são renomados capitalistas, mas sim, entram em Moçambique para se endividar no exterior. É preciso uma política empreendedora do setor privado nacional, para que seja ele a se endividar do que alguns estrangeiros fracos.

Estes dados confirmam que de fato os novos atores de cooperação internacional estão ganhando terreno, não só em Moçambique, mas também em todos ao países africanos. Nesse sentido, o domínio tradicional do Ocidente em África nas áreas de petróleos, minérios, finanças, manufatura, assistência técnica, doações e IDE está sendo desafiado 
com a chegada de novos atores. Isto representa Southall and Melber (2009) e Brautingam (2009) o fim do imperialismo informal dos EUA.

Por seu turno, Chichava (2010, p. 337) confirma estas idéias ao mostrar que "o investimento direto chinês em África, passou de 49 milhões de dólares americanos em 1990 para 2.6 bilhões de dólares em 2006, tendo a China se transformado no terceiro parceiro em África depois da União Européia e dos Estados Unidos". A importância da China para África e vice-versa aumento bastante, de tal modo que foi criado em 2006 (ano de África) o Fórum de Cooperação China - África (FOCAC). Foi na cimeira de 2006, na capital chinesa, que a China afirmou incrementar de 190 para 440 o número de produtos africanos isentos de tarifas de importação no mercado chinês até 2009. Paradoxalmente, o aumento espetacular do comércio entre a China e África é ainda marginal (3.3\% em 2007 passando para $4.8 \%$ em 2008) quando comparado com outros continentes nos quais a China investe o que em termos reais e de acordo com Brautingam $(2009$, p. 3) significou acima de 20 bilhões de dólares norte-americanos e recentemente (2015), só na América Latina, 53 bilhões de dólares norte-americanso. Adicionalmente, África ainda exporta menos para China do que exporta para União Européia e, com razão, dada à menor capacidade de competitividade dos produtos africanos na China considerando os preços dos produtos chineses. Chichava (2010) e Brautingam (2009, p. 3) asseveram que os interesses chineses em muitos continentes levantam muitas inquietações: "para além das óbvias perdas comerciais que tal fenômeno traz a estes países, China é também acusado de fazer recuar a democracia, cooperando com regimes ditatoriais, autocráticos e corruptos [...]". Adicionalmente, China é acusado de mau doador, ao lado do Brasil e Índia como indica Inoue and Vaz (2013) ao apontar que nos últimos seis anos apesar de Brasil receber assistência técnica e financeira bilateral e multilateral passou a ser um doador significante, o que desperta a atenção do mundo. À semelhança da China, o Brasil não usa a linguagem tradicional de assistência ao desenvolvimento dos países centrais. Para além de estes países emergentes não condicionarem as suas doações, empréstimos, assistência técnica a reformas do modelo econômico, político ou direcionar tais empréstimos ou investimentos a áreas de sua preferência como acontece com os países ocidentais.

As críticas à reemergência da China em África apontadas por Southall and Melber (2009), Chichava (2010) e Brautingam (2009) não só provêem de autores ocidentais, como também de autores africanos, da sociedade civil, dos líderes de partidos políticos entre outros estratos sociais africanos. Na República Democrática do Congo, por exemplo, o líder do Congresso Nacional para a defesa do Povo (CNDP) é citado a empreender uma luta titânica pela revisão dos contratos com as empresas chinesas que os considera desastrosos para o país. Outro exemplo está associado a morte de alguns mineiros na Zâmbia, exploração da mão-de-obra zambiana - no que é comumente conhecido como trabalho escravo. A lista das atrocidades ou o que este estudo considera dilemas das empresas chinesas é enorme. Todavia, a maioria dos líderes africanos no poder não tem a mesma visão negativa da China, mas o tomam como bóia de salvação de África contra a secular exploração ocidental. 0 ex-presidente moçambicano, Armando Emílio Guebuza, por exemplo, é citado por Chichava (2010) afirmando que "o que leva o povo chinês a África é uma vontade genuína de ajudar os povos do continente africano, a acelerar seu desenvolvimento, tal como naqueles anos em que se envolveram no apoio de libertação do colonialismo". o autor interpreta Guebuza dizendo que ao afirmar que China quer explorar os africanos não passaria de uma acusação de má fé do ocidente e não seria novidade, dado que, Chichava continuando a citar Guebuza "já nessa altura [da luta contra o colonialismo] 
alguns países ocidentais acusavam a China de estar explorando o seu sistema comunista, mas nós já sabíamos que não passava de uma acusação infundada" (CHICHAVA, 2010, 338). Usado o caso da exploração da madeira em Moçambique pela China, o autor mostra como os discursos políticos sustentam o pleno processo de acumulação primitiva da elite política moçambicana. Este fato põe em risco, de acordo com o autor, a perspectiva de Moçambique beneficiar de uma relação saudável e sustentável para sua economia. 0 autor confirma que China representa de fato, uma reedição das relações que a África estabelece com o Ocidente e limita a perspectiva do desenvolvimento africano. No entanto, o autor não explica por que é que após 40 anos de cooperação com o ocidente tais relações não geraram resultados esperados? De que relação saudável e sustentável está falando? A de colonização e/ou neocolonização? Por que é que após o derramamento de oleodutos na Bacia do Rovuma pela empresa norte-americana Anadarko em 2014 a literatura nacional se manteve, salvo o erro, silenciosa? o que se diz pelo mundo fora sobre a exploração do gás de Temane e Pande pela empresa sul africana Sasol que o Banco Mundial negou fazer uma avaliação objetiva como mostra o relatório do CIP? Ao que parece, o que conta na literatura não é apenas a gravidade dos males praticados por este ou aquela empresa chinesa ou de mais países, mas o mais crítico é o debate literário seletivo que se faz. Disto, pode se chegar a ilação de que não é que China é o único predador de recursos africanos, mas sim, suas práticas são mais divulgadas e discutidas, como forma de perpetuar a perene exploração ocidental e desencorajar o acesso da China aos recursos africanos.

Quanto a este estudo, embora reconhecendo as posições críticas sobre a nova era de cooperação África - China no geral e com Moçambique em particular, não dá para associar o atraso econômico africano às recentes relações África - China. $\mathrm{O}$ que torna menos evidente o argumento da literatura ocidental quanto de alguns intelectuais africanos e moçambicanos em particular é que não apresentam evidência de desaceleração econômica das economias africanas, como resultado da presença chinesa em África. Dados publicados tanto pela PNUD (2013) quanto pelos relatórios do GBAfD e OCED de 2008 e 2015, mostram um desempenho crescente das economias africanas e um dos fatores dessa saúde econômica está relacionada com a demanda de recursos minerais pela China em África para além dos seus espetaculares investimentos. Como foi discutido na primeira parte deste artigo, especificamente páginas 8 e 9 a tendência de redução da Assistência Pública ao Desenvolvimento (APD), da Ajuda Oficial Global para o Desenvolvimento (ODA), assim como dos investimentos e assistência técnica dos países centrais não pode ser associada à presença chinesa em África, mas sim, a dois fatores. Um desses fatores que é comumente citado está relacionado com a crise financeira que tem afligido o ocidente e o outro é a tendência crescente de auto-suficiência fiscal das economias africanas conseqüente de profundas reformas em mais de 40 países com destaque para República Democrática de Congo, Egito, Nigéria, Botsuana, Burkina-Faso, Burundi, Cabo Verde, Gana, Namíbia, Moçambique. As reformas no setor bancário, na lei de investimentos, na criação das Zonas Econômicas Especiais (ZEE) e Zonas Francas Industriais (ZFI), para além da estabilidade política permitiram o aumento do fluxo do IDE, com particular destaque para entrada de países asiáticos Singapura, Índia, Malásia e China. De acordo com o relatório do GBAfD e OCED (2008, p. 21) em 2006 - ano de África, o continente assinalou a entrada de empresas transnacionais asiáticas com 9 mil milhões de dólares em fusões e aquisições transfronteiriças, substituindo pela primeira vez as tradicionais economia dos países desenvolvidos. 0 relatório continua apontando que dos 442 novos investimentos realizados em África em 2006, 258 foram de empresas transnacionais de países desenvolvidos e 175 de empresas transnacionais em via de 
desenvolvimento, dos quais 134 são da Ásia e os restantes de África, cuja relevância significativa em termos de investimentos dentro do continente está a África do Sul.

O relatório do GBAfD e OCED de 2008 aponta como resultado das reformas econômicas e estabilidade política que permitiu África registrar o crescimento real do PIB de 2.7 por cento em 2007, pelo quinto ano consecutivo, bem acima de tendências de longo prazo e o PIB per capita cresceu 3.7 por cento. Para explicar este crescimento o relatório aponta dois fatores: a forte procura externa por exportação de mercadorias, especialmente petróleo e minerais não petrolíferos, o aumento de investimento neste setor e as boas condições de crescimento no setor agrícola. O crescimento médio total foi de 5.9\%, 5.7\%, $5.9 \%$ e $5.9 \%$ em 2006, 2007, 2008 e 2009, respectivamente. Para o caso específico de Moçambique, o crescimento econômico foi de 7 por cento em 2006 e 2007 e isto mostra que mesmo com a presença chinesa o ritmos anterior de crescimento econômico não alterou. Apesar de a Zâmbia ser apontado como uma das vítimas da presença chinesa como aponta Chichava (2010) e Brautingam (2009), a economia deste país manteve um crescimento de 5.8 por cento e a Namíbia é que registrou abrandamento no seu crescimento e a Suazilândia manteve crescimento baixo, igualmente com o Zimbábue com $6 \%$ em 2007, quando comparado com o ano anterior. De acordo com o relatório do GBAfD e OCED (2008, p. 27) a entrada nas Maurícias e Madagáscar de investimentos da China, da Índia e do Bangladesh e o desempenho positivo da indústria têxtil permitiram um crescimento positivo de $6.3 \%$ e $5.6 \%$, respectivamente.

O relatório do Grupo do Banco Africano do Desenvolvimento (GBAD) e da Organização para Cooperação Econômica e Desenvolvimento (OCED) aponta que apesar das adversidades regionais e globais e para o efeito deste estudo, da presença chinesa e dos mais atores emergentes, África cresceu 3.9\% em 2014, o que representa uma ligeira melhoria em relação ao crescimento de 3.5\% registrado em 2013, sendo superior a taxa de crescimento global de 3.3\%. De acordo com a fonte, esta percentagem de crescimento econômico de África é em termos relativo, igualmente superior que a da Ásia Ocidental (2.9\%) e a da América Latina e Caraíba (1.2\%). Todavia, África cresce a um ritmo mais lento do que os mercados emergentes e as economias dos países em desenvolvimento, que registraram um crescimento de $4.4 \%$ (GBAD, 2014, p. 4). A fonte continua apontando que o desempenho da economia mundial tem sido puxado pela China e sendo assim, qualquer choque no crescimento da economia chinesa tem impacto direto na economia global e na percepção dos investidores. Em termos do crescimento regional em África, o GBAD e OCED (2014, p. 5) mostram que África Oriental registrou o crescimento mais elevado do continente com $7.1 \%$, em comparação com os $4.7 \%$ de 2013. O relatório aponta como países que ajudaram para esta dinâmica Etiópia (10.3\%), Ruanda (7.0\%) e Tanzânia (7.2\%). Apesar da persistência de conflito em partes da região da África Ocidental, das elevadas perdas humanas e econômicas provocadas pela Ébola (Guiné, Libéria e Serra Leoa e com alguns casos também na Nigéria, Mali e Senegal) e do declínio acentuado dos preços do petróleo, a região cresceu em média 5.7\% em 2013, tendo passado para 6.0\% em 2014, tendo sido puxados pelo crescimento de $8.3 \%$ e $6.3 \%$ da Costa de Marfim e Nigéria, respectivamente. $\mathrm{O}$ relatório adianta ainda que a explosão dos setores não petrolíferos na região da África Central ajudou-a a atingir uma taxa de crescimento médio de 5.6\% (2014) em comparação com $4.1 \%$ em 2013, com destaque para a relevância do crescimento de 5.1\% do Gabão. Nota que o Gabão é uma das maiores fontes de exploração de madeira pela China, cujo desempenho do setor de transformação de madeira é destacada pelo relatório do GBAfD e OCED, o que compensou a queda do preço do petróleo. 0 relatório mostra que 
os estrangulamentos (escassez de eletricidade, tensas relações industriais) da principal economia da região da África Austral, a África do Sul e outros problemas adversos da região levaram a um abrandamento do crescimento desta região para $2.7 \%$ em 2014 contra 3.6\% de 2013. Todavia, o desempenho da economia moçambicana com uma taxa de crescimento de 7.6\% em 2014 em comparação com 7.4\% em 2013 é apontado pelo relatório como sendo a economia regional com rápido crescimento, impulsionado pelo IDE na prospecção de minerais, gás e petróleo. Da mesma forma, a Zâmbia e o Malawi registraram taxas de crescimento impressionante de $5.7 \%$ cada um, em comparação com 6.7\% e 6.1\%, respectivamente de 2013. A economia da Namíbia cresceu $5.3 \%$ em comparação com 5.1\% em 2013 (GBAfD e OCED, 2015, p. 5). O crescimento do Norte da África registrou uma ligeira subida de 1.7\% em 2014 em relação à taxa de 1.6\% de 2013. De um modo geral, o crescimento foi mais elevado nos países de baixo rendimento como Costa de Marfim; República Democrática de Congo com um crescimento de 8.9\%, como resultado da dinâmica da extração mineira, agricultura e investimento em infraestruturas e Etiópia com um crescimento médio de $8 \% .0$ abrandamento das economias do Guiné, Libéria e Serra Leoa é associado tanto pelo GBAfD e OCED quanto pelo Banco Mundial ao surto da Ébola. Tal abrandamento significou salto decrescente do PIB estimado para 2014 de $6.2 \%$ para 4.3\% em Junho de 2014 e em Janeiro de 2015 para $0.9 \%$ no caso da Guiné. Relativamente a Libéria o decréscimo foi de uma estimativa de $2.3 \%$ para todo o 2014, para 6.8\% em junho de 2014 e 3.8\% em janeiro de 2015. Quanto a Serra Leoa saiu de uma estimativa de 5.0\% para 8.9\% em junho de 2014 e em janeiro de 2015 registrou (-) 2.5\%. Estes dados refletem a gravidade da catástrofe que de acordo com a Organização Mundial da Saúde (apud GBAD, 2014, p. 6) até final de dezembro de 2014 o vírus da Ébola havia sido registrado 20.200 casos da doença, provocado a morte 7.904.

Estes dados do Banco Mundial quanto do GBAfD e OCED ajudam a sustentar o argumento deste artigo que não só desassocia o abrandamento de algumas economias africanas à presença chinesa em África em geral e de Moçambique em particular, como também, defende que em parte o desempenho das economias africanas é produto da presença chinesa. A nível global, este argumento mantém-se válido, dado que a industrialização da China, em particular a indústria manufatureira elevou para cima o preço das commodities e por via disso muitas economias, sobretudo as do sul apresentaram um desempenho significativo. De acordo com o relatório do Programa das Nações Unidas para o Desenvolvimento (PNUD) de 2013, o comércio de mercadorias Sul-Sul entre 1980 a 2010 passou de $25 \%$ a $47 \%$ e no produto mundial passou de $33 \%$ a $45 \%$ e o comércio desta região aumentou de 8,1\% a 26,7\%. Em termos do Índice de Desenvolvimento Humano (IDH), o relatório aponta que de 1990 a 2012 mais de 40 países registraram ganhos mais que significativos do que o previsto. Os maiores progressos no IDH, de acordo com o mesmo relatório foram registrados nos países do Sul e nenhum país não teve melhorias. $\mathrm{Na}$ mesma perspectiva de demonstrar o desempenho das economias africanas, Southall and Melber (2009, p. 71 - 72) mostram que para o caso africano a presença da China contribui para melhoria dos termos de troca no comércio internacional. Os autores apontam ainda que não são apenas visíveis para a economia africana, mas também novos empresários estrangeiros foram atraídos e se estabeleceram em África. Southall and Melber (2009) e Brautingam (2009, p. 40 e 72) citam a construção de estádios nacionais, estradas, indústrias farmacêuticas (principalmente na Tanzânia) entre outras infra-estruturas, construção de casas e edifícios governamentais, com maior destaque para o projeto de construção de 2000 quilômetros de linha féria entre Zâmbia e Tanzânia. No contexto do 
Sino-África, o comércio passou de 5 bilhões em 1997 para 55,5 bilhões de dólares em 2006, com estimativas de alcançar 110 bilhões de dólares americanos em 2011.

Voltando ao caso Moçambicano, objeto de estudo deste artigo, convém apontar que como foi descrito de forma sintética na primeira parte deste estudo, o saldo do fluxo de bilhões de dólares e assistência técnica em Moçambique após cerca de 40 anos de cooperação ainda que gigantesco, não foi capaz de criar o bem-estar à maioria da sociedade moçambicana e construir uma capacidade institucional fiável. Castel-Branco (2011, p. 111) sustenta este argumento ao afirmar que "a ajuda externa é ineficaz e/ou prejudicial por causa dos condicionalismo econômicos e políticos que introduz, por permitir sustentar ambiente econômico não competitivo e por fomentar corrupção". O segundo argumento forte deste autor aponta que os líderes dos países dependentes da ajuda externa tendem a prestar contas aos doadores e não aos cidadãos dos países receptores de donativos. É neste contexto de total isolamento dos cidadãos do país receptor que se formulam políticas públicas, como maior interação apenas entre governo e os doadores. Como é defesa deste estudo, as instituições moçambicanas são incapazes de combater a corrupção e de construir um ambiente e arranjo institucional que configura um Estado de Direito.

Essa literatura anti-chinesa não apresenta dado sobre o quanto se desacelera o crescimento e desenvolvimento econômico de África em geral e de Moçambique em particular devido à presença da China em particular e dos novos atores internacionais (Brasil, Índia, China e África do Sul), em geral. Pelo contrário, apresentam dados sobre os ganhos dos países fruto da presença chinesa. Testam esta afirmação os dados apresentados nos primeiros parágrafos desta segunda parte do trabalho. Como também foi apresentando na primeira parte deste trabalho, a China ajudou Moçambique a se libertar dos perenes colonos ocidentais, que regra geral, os países ocidentais apoiavam a colonização portuguesa em Moçambique. É lastimável a força do discurso e propaganda ocidental para manter o neocolonialismo em Moçambique. Sem negar as evidências de interesses particulares da elite política moçambicana no contexto da atual acumulação primitiva, também não dá para aceitar as acusações de que a China vai regredir o desenvolvimento socioeconômico moçambicano. Deste modo, mais do que este estudo aplaudir a visão de Guebuza sobre a real intenção chinesa em Moçambique, apela mais investigações e debates. Não se pretende com isso afirmar a sobreposição dos interesses chineses em Moçambique, pelos nacionais, mas afirmar que a China já fez muito em pouco tempo sem, no entanto entrar em comparação com a ainda presente e necessária assistência técnica e financeira de alguns países ocidentais.

Os dilemas da cooperação Moçambique - China, ou seja, exploração desenfreada de madeira ${ }^{16}$, dos mariscos e outros recursos naturais moçambicanos, para além, da desumana exploração da mão-de-obra, estão associados, principalmente à incapacidade dos arranjos institucionais. Isto por que as questões sobre a acumulação primitiva da elite política moçambicana não têm como gênese a nova era de cooperação com a China, mas estão associados com o modo como Moçambique criou seu ambiente e arranjo institucional, sob assistência técnica e financeira dos países centrais.

Só para sustentar este argumento, convêm apresentar algumas evidências exemplificativas entre tantos casos candentes e problemáticos sobre as quais Moçambique é burlado por muitas empresas que não sejam chinesas. Começando mesmo pelo orçamento do Estado que é dependente dos donativos do G 19, anualmente este grupo de países da OCED ameaça a não continuar a alocar os seus donativos ao orçamento do Estado moçambicano devido a desgastante falta de transparência no uso dos mesmos 
pelo governo moçambicano. Outros casos mediáticos são dados pelo Centro de Integridade Pública (CIP), para além dos jornais moçambicanos. $O$ relatório $\mathrm{n}^{\circ} 2$ do Centro de Integridade Pública (CIP) de Fevereiro de 2015 mostra como as multinacionais americana e italiana, Anadarko e Eni, respectivamente, conseguiram assegurar contratos generosos nos Projetos de Gás Natural Liquifeito nas áreas 1 e 4 na bacia do Rovuma, na província nortenha de Cabo Delgado. No seu relatório no 12 de 2014, o CIP deplora a exploração das areias pesadas de Moma pela empresa Kenmare nem pagar impostos e nem desenvolvimento econômico e social local, conforme o previsto nos contrato de concessão. Em termos substanciais, o relatório aponta que "por cada dólar que a Kenmare ganhou exportando minerais de Moçambique entre 2008 a 2011, Moçambique recebeu apenas um cêntimo de pagamento de imposto" (CIP, 2014, p. 1). Isto significa que dos 326,7 milhões de dólares que a empresa irlandesa ganhou em receitas, apenas pagou ao Estado moçambicano 3,5 milhões de dólares. O Projeto de Gás Regional da África Austral entre a República de Moçambique e a República de África do Sul de exploração de gás pela empresa Sul africana Sasol em Pande e Temane, na província sulista de Inhambane que dura há mais de uma década, é um dos fracassos em termos de receitas para Moçambique. No seu relatório $\mathrm{n}^{\circ} 11$ de 2014, o CIP aponta que o Banco Mundial recusa-se a avaliar honestamente os benefícios econômicos da Sasol Pande Temane. Tal recusa está associada aos fabulosos lucros que a África do Sul ganha em detrimento de Moçambique neste projeto. Por exemplo, o relatório aponta que

a Sasol transfere a maioria esmagadora de lucros de Moçambique para África do Sul por causa de um acordo de preço lesivo. [...] a Sasol compra gás com base nos termos de acordo original de $\$ 1.50$ por giga joules e está agora a pagar cerca de $\$ 3.00$ [...] e vende o gás na África do Sul com base no acordo original, chegando a vender acima de $\$ 7.00$ a $\$ 14.00$ giga joules na África do Sul (CIP, 2014, 2).

No seu relatório $\mathrm{n}^{\circ} 11$ de 2014, o CIP fala do contrabando de madeira envolvendo empresas chinesas (Xue Bing Huang), na província central da Zambézia. Tal contrabando é produto da emissão pela Direção Provincial de Agricultura da Zambézia de uma licença de corte e transito de madeira. Entra na lista de fracassos em termos de ganhos fiscais para Moçambique a empresa Alumínio de Moçambique - Mozal, uma das multinacionais renomada de Moçambique.

A lista de casos problemáticos e lesivos ao Estado Moçambicano é enorme e não caberia nestas páginas, mas esta pequena enumeração serve para demonstrar que não são apenas as empresas chinesas o cerne da questão, mas de todas as empresas estrangeiras e até nacionais, em conivência ou com elite política moçambicana ou com o próprio Estado no contexto das limitações impostas a este pelas teorias liberais e neoliberais. Sendo assim, é fácil perceber que os problemas de pilhagem e dilapidação de recursos minerais em Moçambique se inserem na conjuntura global da expansão do capital financeiro. É neste âmbito que Castel-Branco (2013, p. 100) citando a cimeira do G.8 na Grã-Bretanha, aponta que "se as multinacionais pagassem imposto nas economias subdesenvolvidos em que operam, dependência externa tornar-se-ia um fenômeno do passado". Todavia, a idéia da globalização do fenômeno e as demonstrações de que quase todas as empresas nacionais e estrangeiras que operam em Moçambique têm uma ação lesiva ao Estado, não pretende legitimar os dilemas lesivos ao Estado moçambicano na cooperação Moçambique - China, mas evidenciar que nenhum ganho será possível enquanto o ambiente e o arranjo institucional permanecer permeável aos interesses estrangeiros e nacionais lesivos. A China chegou e encontrou um ambiente e arranjo institucional permeável e aliciante a práticas lesivas e aprendeu a lição. A impermeabilidade do ambiente e arranjo 
institucional passa primeiro, pelo cumprimento rigoroso do plasmado na Constituição da República sobre a separação de poderes, dando maior autonomia ao poder judiciário para investigar e punir exemplarmente os casos lesivos ao Estado. Para que isso aconteça é preciso que o Estado não se confunda com o partido no poder. Segundo, por uma atitude de responsabilidade coletiva pelos bens públicos, sobretudo da elite política que compõem a máquina governamental.

51 Todavia, apenas a um nível de abstração mais elevado e com uma visão genérica das causas globais das ações lesivas aos estados pelas multinacionais de forma geral, é que é possível encontrar as causas primeiras do fenômeno e no contexto das metamorfoses do capital financeiro. A transfiguração, como mostra Karl Marx do valor de uso em valor de troca gerando a cambiabilidade mercadológica de tudo (inclusive a vida humana) é uma dessas causas. A vitória das teorias do liberalismo clássico como defende o livro de Friedrich Hayek, publicado em 1944 e para Perry Anderson (2000) o nascimento após a Segunda Guerra Mundial (IIGM) do neoliberalismo na Europa e América do Norte, não só explica a derrota do socialismo para guiar as relações da vida humana, como também fazem desta o objeto do lucro. Hayek (2010) na defesa do liberalismo e Anderson (2000, p. 9) interpretando os argumentos neoliberais apontam que "as limitações dos mecanismos do mercado por parte do Estado afigura-se uma ameaça letal à liberdade, não somente econômica, mas também, política". De acordo com Anderson (2000) a derrota do keynesianismo e do solidarismo preparou as bases para outro tipo de capitalismo, duro e livre de regras para o futuro. A consequiência imediata dessa vitória são as desigualdades sociais e a transmutação da vida humana, havendo pessoas altamente abastadas e outras sem mínimas condições de subsistência. David Harvey (2013, p. 43) mostra que em 1996 o patrimônio líquido das 358 pessoas mais ricas do planeta era igual à renda combinada de $45 \%$ da população mundial, ou seja, 2.3 bilhões de pessoas. 0 que é ainda pior prossegue o autor, é que as 200 pessoas mais ricas do mundo, dobraram o seu patrimônio líquido, nos quatro anos anterior a 1998, para mais de 1 trilhão de dólares. Os ativos dos três maiores bilionários do mundo alcançaram na época um valor superior ao PIB de todos os países menos desenvolvidos e sua população de 600 milhões de pessoas. Dados recentes apontados por Theotônio dos Santos (2014) indicam que 1\% de cidadãos mais ricos do mundo é proprietária de $47 \%$ da riqueza mundial. Estes dados revelam basicamente o quão os estados nacionais são dilapidadas pelas empresas sejam elas nacionais, transnacionais e/ou multinacionais. O que realmente está acontecer no mundo atual é que, como mostra Stiglitz (paud Harvey, 2013, p. 84) os países pobres estão na verdade a subsidiar os países ricos. Assim, é lícito e em jeito conclusivo afirmar que enquanto os paradigmas econômicos e políticos continuarem egoístas, ou seja, com baixa distribuição da renda e restauração dos estados do bem-estar a nível global os recursos dos países pobres continuaram a ser dilapidados pelas empresas dos Estados ricos.

\section{Conclusão}

O texto em tela quis analisar os ganhos para Moçambique na sua relação diplomática com a China. A partir das fervorosas controvérsias sobre a emergência da China e os perigos que isso representa para o desenvolvimento saudável e sustentável de Moçambique, o estudo procurou capturar as evidências empíricas e/ou históricas que fazem da China um mau doador e/ou investidor. Com base na revisão da literatura, na qual se procuravam evidências históricas de desaceleração da economia moçambicana como resultado da 
presença chinesa foi possível confirmar a hipótese de investigação. Ou seja, não é que a China seja má doadora e/ou investidora ou, ainda, constitua um risco para o desenvolvimento saudável e sustentável de Moçambique, mas a dimensão política moçambicana como componente para entender a capacidade institucional do Estado para além da sua associação a interesses particulares e partidários é frágil para se lidar com os interesses do gigante chinês, ainda que tais interesses se situem, de fato, no contexto de win-win cooperation, como defende a política externa chinesa.

Para sustentar esta hipótese o artigo tomou como indicadores a análise do comportamento dos ganhos para Moçambique ao longo do tempo na sua relação diplomática com a China. Ao examinar esse comportamento, o estudo conclui que os ganhos para Moçambique na sua relação diplomática com a China são avultados e visíveis. Desde a Luta de Libertação Nacional, China sempre esteve presente e ajudou a emancipação política e atualmente econômica do país. Numa primeira fase, não só investiu na área militar, como também na agricultura, saúde, entre outras áreas. A partir dos anos 2000 e, sobretudo com a realização em 2006 do Fórum de Cooperação China África (FOCAC) que criou condições diplomáticas para o crescente aumento da ajuda técnica e financeira da China em Moçambique, para além dos avultados investimentos em várias áreas. Com destaque para infra-estruturas, cujas obras são visíveis a olho nu, sobretudo na capital Maputo; defesa e segurança; agricultura; construção; assinatura e implementação de vários acordos comerciais, perdão da dívida e avultados investimentos diretos. Os dados do CPI e da GAZEDA apontam que China tem atualmente 133 projetos de investimentos aprovados, gerando 26.133 mil novos empregos, num investimento de aproximadamente 2 mil milhões de dólares norte-americanos, para além do financiamento de 2,3 bilhões de dólares norte-americanos para a construção de uma das maiores barragens africana - Mpanda Nkuwa.

Para além dos ganhos para Moçambique, o estudo avaliou também, a tendência do fluxo da ajuda externa, doações, assistência técnica e financeira, o Investimento Direto Estrangeiro (IDE) e o desempenho de algumas economias africanas. A finalidade de análise destes indicadores eram verificar o seu comportamento, ou seja, se apresentavam tendências de retração ou desaceleração passível de ser associada ao crescente aumento da presença chinesa em Moçambique em particular e em África no geral. Os resultados desse exercício permitiram perceber que não existem evidências históricas para uma visão pessimista sobre a China. Sustentam este argumento a manutenção e o crescimento tanto das principais fontes de financiamento externo em África (APD, ODA, IDE, as remessas da diáspora africana), assim como o crescimento das economias áfricas. Contrariamente aos estudos que mostram que o fluxo de capitais estrangeiros está abrandando desde os anos 2000, ele alcançou US $\$ 200$ mil milhões $2014 \mathrm{em}$ toda a África, contra as previsões de que este alcançaria US\$195 mil milhões em 2015. Ao contrário do que tem sido literalmente apresentado de que a presença da China em África em geral e Moçambique em particular, é um risco para o desenvolvimento econômico, foi, paradoxalmente, a presença chinesa que acelerou o crescimento econômico e o fluxo do IDE, não só em África, mas também, a nível mundial. Para o caso africano, os dados do GBAfD e da OCED de 2008 e 2015 sobre o fluxo tanto da Assistência Pública ao Desenvolvimento (APD), Ajuda Oficial Global para o Desenvolvimento (ODA) quanto sobre o IDE e as remessas da diáspora africana ainda que tenham provavelmente diminuído o ritmo de crescimento, eles aumentaram. O IDE, por exemplo, aumentou cerca de $60 \%$ de 
2002 a 2014, ao se situar nos 60.4 bilhões de dólares, face aos 36 bilhões de 2002. A ODA ultrapassou US\$ 5 mil milhões em 2014 a previsão de este alcançar os 195 mil milhões.

Quanto ao crescimento econômico o relatório do GBAfD e OCED de 2015 aponta que África cresceu 3.9\% em 2014, o que representa uma ligeira melhoria em relação ao crescimento de $3.5 \%$ registrado em 2013, sendo relativamente superior a taxa de crescimento global de 3.3\% e da Ásia Ocidental (2.9\%) e América Latina e Caraíba (1.2\%), estando abaixo apenas ao crescimento das economias emergentes de $4.4 \%$. Para este estudo, o desempenho econômico global, considerando a crise financeira das economias centrais só pode ser explicado tomando a China, a Índia como referências. Foi a demanda de matérias-primas pelas indústrias chinesas que elevou para cima o preço das commodities o que alargou a balança de pagamento de muitas economias globais.

Relativamente aos debates sobre os dilemas associados à dilapidação de recursos naturais, em particular madeira, recursos marinhos, entre outros, ao "trabalho escravo" e fuga ao fisco, o estudo encontrou evidência empíricas e tal como mostra a hipótese de investigação, este fato, está associada em parte à fragilidade do ambiente e arranjo institucional criado sob assistência técnica e financeira dos países centrais. 0 estudo mostrou as controvérsias, por exemplo, sobre as isenções e outras benesses concedidas às multinacionais pelo Estado, tal é o caso da Mozal, Sasol, Kenemare, Vale Moçambique, entre outras. Ao lado dessas benesses, estão os interesses particulares da elite política moçambicana o que gera uma espécie de protecionismo não só às empresas chineses, mas a todas aquelas que interessam essa elite.

A fragilidade do ambiente e arranjo institucional constitui o terreno fértil sobre o qual os novos atores de cooperação com Moçambique, em particular a China posam e perpetuam as perdas fiscais e alargam a dependência externa. Esta realidade está no centro dos debates e dilemas que acabam associando a pobreza moçambicana a esses novos atores. Um fato não confirmado neste estudo considerando que a emergência da China como ator-chave das dinâmicas da economia mundial e moçambicana em particular não contêm evidências de desaceleração econômica conseqüente da presença chinesa em Moçambique. As evidências históricas encontradas na literatura demonstram um excelente desempenho da economia mundial em geral e africana em particular, puxadas em parte pela demanda de matérias-primas pela indústria asiática, especialmente a chinesa e a indiana.

Todavia, para além de este texto sugerir a separação de poderes conforme plasmado na Constituição da República de Moçambique de modo a dar maior dinamismo ao poder legislativo e judiciário em particular permitindo criar um ambiente e arranjo institucional sólido, as atrocidades das multinacionais e transnacionais devem ser analisadas de forma global. As metamorfoses do capital financeiro, ou seja, a transfiguração, como mostra Karl Marx do valor de uso em valor de troca gerando a cambiabilidade mercadológica de tudo são a causa primeira dos dilemas que enfermam os Estados nacionais na sua relação com as multinacionais. 


\section{BIBLIOGRAFIA}

ARTHUR, W. Brian. Positive Feedbacks in the Economy: A New Economic Theory elucidates mechanisms whereby small changes events early in the history of an industry or technology can tilt the competitive balance, Stanford University, 1990.

ASSEMBLEIA DA REPÚBLICA DE MOÇAMBIQUE. Constituição da República, Maputo, 1990. . Bolentim da República: Lei no 29/2014, de 9 de Setembro - Acordo de Cessação das Hostilidades Militares, I Série - Número 72, 4º Suplemento, Imprensa Nacional de Moçambique, E.P, Maputo, 2014.

Bolentim da República: Lei nº 30/2014, de 26 de Setembro - Legislação Eleitoral, I Série - Número 78, Suplemento, Imprensa Nacional de Moçambique, E.P, Maputo, 2014. Banco Africano de Desenvolvimento (BAD) e Organização para Cooperação Econômica e Desenvolvimento (OCED). Perspectivas Econômicas na África: Estudos de Países: Angola, Cabo Verde e Moçambique, Centre development of OCED, WWW.oecd.org/dev/aeo, 2008.

BOBHAN, R. Aid Dependence and Donor Policy: The Case of Tanzania with Lessons from Bangladesh's Experience.IN: Sida . Aid Dependency: Causes, Symptoms and Remedies, project 2015, Bangladesh, 1996.

BOND, Patrick. O Império Norte-Americano e o Subimperialismo Sul-Africano. In: PANITCH

Leo e LEYS, Colin. O Império Realoaded, Editora Marlin Press CLACSO, São Paulo, 2005.

BORON, A. A. Império e Imperialismo: Uma Leitura Crítica de Michael Hardt e Antonio Negri, $1^{a}$ edição, Bueno Aires: Clacso, Tradução de: Lilian Koifman, 2002.

BRAUTINGAM, Deborah. Aid Dependence and Governance, Norstsedts Tryckeri AB, Oxford University Press, New York, 2000.

BRAUTINGAM, Deborah. The Dragon's Gift: The Real Story of China in Africa, Oxford University Press, New York, 2009.

CASTEL-BRANCO, Carlos Nuno. Desafios da mobilização de recursos domésticos: revisão crítica do debate. IN: DE BRITO, Luís et. al. (Org.). Desafios para Moçambique 2012. Editor: Instituto de Estudos Sociais e Econômicos, Maputo, 2012.

. Refletindo sobre acumulação, porosidade e industrialização em contexto de economia extrativa. IN: DE BRITO, Luís et. al. (Org.). Desafios para Moçambique 2013. Editor: Instituto de Estudos Sociais e Econômicos, Maputo, 2013.

Dependência de Ajuda Externa, Acumulação e Ownership - contribuição para um debate de economia política, Editora IESE, Maputo, 2011.

CASTEL-BRANCO, Carlos Nuno e OSSEMANE, Rogério. Crises Cíclicas e Desafios da Transformação do Padrão de Crescimento Econômico em Moçambique. IN: DE BRITO, Luís et al. Desafios para Moçambique 2010. Editor: Instituto de Estudos Sociais e Econômicos, Maputo, 2010.

CENTRO DE INTEGRIDADE PÚBLICA. Análise do decreto-lei do LNG do Rovuma: Multinacionais a Seguram Termos Generosos. Edição № 02/2015, fevereiro, Maputo, 2014. 
. Partido Frelimo financia-se com dinheiro de contrabando de madeira na Zambézia, Edição № 11/2014, outubro, Maputo, 2014.

Banco Mundial Recusa-se a Avaliar Honestamente os Benefícios Econômicos da Sasol Pande Temane, Edição № 11/2014, dezembro, Maputo, 2014.

Exploração das areais pesadas de Moma: nem imposto, nem desenvolvimento econômico e social local, Edição № 12/2014, novembro, Maputo, 2014.

CHICHAVA, Sergio. Moçambique na Rota da China: Uma oportunidade para o Desenvolvimento? IN: DE BRITO, Luís et al. Desafios para Moçambique 2010. Editor: Instituto de Estudos Sociais e Econômicos, Maputo, 2010.

DAVID, Paul A. Why are the Institutions they 'Carriers the History'? Path Dependence and the Evolutions of Conventions, Organizations and Institutions. Oxford University Press, 1994.

DOS SANTOS, Theotonio. Teoria de Dependência: Balanço e Perspectivas, Obras Escolhidas, Vol. 1, Florianópolis: Insular. Reedição ampl. e atual, 2015.

DRÈZE, Jean e SEN, Amartya; Glória incerta: A Índia e suas Contradições, $1^{a}$ Edição, Tradução de Ricardo Doninelli Mendes e Laila Countinho, Editora Companhia das Letras, São Paulo, 2015.

FRANCISCO, António. Sociedade Civil em Moçambique: Expectativas e Desafios. IN: DE BRITO, Luís et al. Desafios para Moçambique 2010. Editor: Instituto de Estudos Sociais e Econômicos, Maputo, 2010.

GOMIDE, Alexandre de Ávila e PIRES, Roberto Rocha C. Capacidades Estatais e Democracia: Abordagem dos Arranjos institucionais para Análise de Políticas Públicas. IN: INSTITUTO DE PESQUISA ECONÔMICA APLICADA (IPEA). Capacidades Estatais e Democracia: Abordagem dos Arranjos institucionais para Análise de Políticas Públicas, Editores: GOMIDE, Alexandre de Ávila e PIRES, Roberto Rocha C. Brasília: Ipea, 2014.

GOVERNO DA PROVÍNCIA DE TETE. Informe sobre as Atividades das ONG'S que Operam na Província de Tete. Tete, Maio de 20008.

HARVEY, D. O Neoliberalismo: História e Implicações. Edições Loyola, Tradução: Adail Sobral e Maria Stela Gonçalves, $4^{\mathrm{a}}$ edição, São Paulo, 2013.

HAYEK, Friedrich. O Caminho da Sirvidão. São Paulo, Instituto Ludwing Von Meses Brasil, $6^{\text {a }}$ edição, 2010.

HOMERIN, Janaína. As Organizações da Sociedade Civil em Moçambique: Atores em Movimento. Embaixada da França em Moçambique, Maputo, 2005.

INOUE, Cristina Yumie Aoki and VAZ, Alcides Costa. Brazil as 'Southern donor': beyond hierarchy and national interests in development cooperation? Cambridge Reviews os international Affairs, Volume 24, Number 4, December 2012.

INSTITUTO NACIONAL DE ESTATÍSTICA. Anuário Estatístico 2013. Maputo, 2013. Anuário Estatístico 2000. Maputo, 2000.

MENICUCCI, Telma Maria Gonçalves.Ruptura e Continuidade: a dinâmica entre o processo decisório, arranjos institucionais e contexto político - o caso da política de Saúde no Brasil, Brasil, 2007.

NORTH, Douglass C. Institutions. Washington University, Jornal of Economic Perspective, Volume 5, Number 1, 1991. 
PEDONE, Luiz. Formulação, Implementação e Avaliação de Políticas Públicas Brasília: FUNCEP, 1986.

PERRY, Anderson. Balanço do Neoliberalismo. IN: SADER, Emir \& GENTILI, Pablo (orgs.) Pósneoliberalismo: as políticas sociais e o Estado democrático. Rio de Janeiro: Paz e Terra, 1995.

PHIRI, Martha and KANNAN, Asha. Mauritius 2014. Disponível em: www.africaneconomicoutlook.org, Acesso em 27 de julho de 2015.

PROGRAMADAS NAÇÕES UNIDAS PARA DESENVOLVIMENTO (PNUD). Relatório de Desenvolvimento Humano de 2013. A Ascensão do Sul: Progresso Humano num Mundo Diversificado. New York, 2013.

ROCHA, Frederico (Coord.). Perspectivas da Política Industrial dos BRICS, Rio de Janeiro, UFRJ, Instituto de Economia, 2008/2009. 278 p. Relatório integrante da pesquisa "Perspectiva do investimento no Brasil", em parceria com o Instituto de Economia da UNICAMP. Disponível em: http//WWW.projetopib.org/?=documentos, acesso em 1 de julho de 2015.

SOUTHALL, Roger and MELBER, Henning (Eds). A New Scramble for África? Impelrialism, investment and development, University of Kwazulu-Natal, 2010.

WACHE, Paulo M.; LUNDIN, Iraê Baptista; FAINDA, Valter e GOMES, Sérgio. As Potências Emergentes na Construção da Multipolaridade Inclusiva: Uma Abordagem Comparativa das Políticas Externas dos BRICS, Editora: Instituto Superior de Relações Internacionais (ISRI), Maputo, 2014.

World Bank. Mozambique Country Economic Memorandum Sustaining growth and reducing poverty, Maputo, 2005.

\section{NOTAS}

1. Termo usado no português moçambicano e demais países para designar porções de terras lavradas ou utilizadas para prática de agricultura. É assim, um terreno agrícola para produção familiar - terreno cultivado.

2. FRELIMO é o partido que liderou a Luta de Libertação Nacional em 1964. Foi fundado em 1962, na Tanzânia pelo Eduardo Chivambo Mondlane, posteriorimente presidente deste partido até à sua morte em 1969. A Frelimo é o partido no poder desde a independência até então.

3. O texto voltará a este assunto central que é a cooperação Moçambique - China na segunda parte após esta breve contextualização sobre a trajetória histórica que levou Moçambique a uma situação de dependência de trajetória.

4. O maior partido da oposição até então que conduziu a guerra civil desde 1976 até 1992 , mediante um Acordo de Paz assinado em Roma com apoio da Comunidade de Santo Egídio da Itália. A guerra civil foi devastadora, com cerca de um milhão de mortos, milhares de refugiados e total destruição de infra-estruturas sociais e econômicas.

5. Atualmente o desemprego em Moçambique é alto e corresponde a $24 \%$, um dado problemático considerando que a maioria da população Moçambicana é jovem e desta $90 \%$ está desempregada.

6. Para aprofundar os fatores financeiros que explicam a dependência externar de Moçambique, consular Castel-Branco e Ossemane (2010, p. 166). Dado que o interesse deste estudo não repetir o víeis econômico e financeiro realizado por Castel-Branco e Ossemane (2010), para explicar a dependência externa de Moçambique (como mostraram os parágrafos anteriores), mas sim, usar as evidências históricas de cunho político-militar e o ambiente e arranjo institucional. 
7. A Nigéria para além de não se um considerável player africano, enferma de conflitos militares com evidência de que recursos naturais - o petróleo nigeriano, são fatores de maldiçoamento social, conseqüente de confluência de interesses externos.

8. São órgãos de Soberania de Moçambique o Presidente da República, a Assembléia da República, o Governo, os tribunais e o Conselho Constitucional.

9. A cidade de Maputo a capital moçambicana e a província de Maputo têm uma população estimada em cerca de 2 milhões habitantes num total de 24 milhões de habitantes em todo o país. 10. Por exemplo, Agência dos Estados Unidos para o Desenvolvimento Internacional (USAID), Visão Mundial, UNICEF, Comissão para as Nações Unidas, MSF Luxemburg, HELPAG Internacional, DANIDA, Rio Doce, Instituto de Medicina Tropical, FNUAP, Agência Japonesa para Cooperação Internacional (JICA), Ajuda de Desenvolvimento do Povo para Povo (ADPP), Agência Suéca no Desenvolvimento Internacional (ASDI); Departamento para o Desenvolvimento Internacional do Governo Britânico (DFID); Agência Dinamarquesa para o Desenvolvimento Internacional (DANIDA); Cooperação Irlandesa; Governo da Noruega; Agência Suíça para Cooperação e Desenvolvimento (SDC); Moçambique e Embaixada da Suécia (IBIS); Canadian International Development Agency (CIDA); Swedish International Development Agency (SIDA) entre tantas outras.

11. Chegando a absorver $75 \%$ do capital investido. Isto mostra que Moçambique é terreno de geração de empregos bem pagos. Disto é possível tirar a ilação de que mais de $50 \%$ do que entra como capital financeiro volta para os países de origem em forma de salários.

12. Indiretamente porque a segunda parte deste trabalho não tem como objetivo responder a esta pergunta sobre o que é que falho na cooperação Moçambique com o Ocidente, mas sim, analisar a cooperação Moçambique - China nua perspectiva de trajetória, ou seja, o que é que Moçambique ganha nessa cooperação de modo a evitar cair no mesmo cenário anterior ou na experiência de forte fluxo de donativos e assistência técnica, mas com resultados desanimadores. Para, além disso, a segunda parte entra na discussão sobre os debates e dilemas sobre a cooperação Moçambique - China.

13. Desde 1994, primeiro ano de eleições presidenciais e legislativas em Moçambique a Frelimo é o partido vencedor das eleições e com maioria parlamentar.

14. Conta também com o financiamento da Índia.

15. Os oitos países incluem: Angola, Congo Brazzaville, República Democrática de Congo, Etiópia, Guiné Equatorial, Gana, Sudão, Zimbábue e Zâmbia.

16. A Madeira é principal produto de exportação de Moçambique para China, cobrindo $90 \%$. 0 que torna Moçambique o sexto país maior exportador da madeira para China. Tal exploração ocorre de forma lesiva ao Estado moçambicano envolvendo empresas chinesas, moçambicanas ligadas a elite política, partido no poder e também a oposição. A exploração da madeira na central província de Moçambique - Zambézia passou de $81 \mathrm{~m}^{3} \mathrm{em} 2003$ para $212 \mathrm{~m}^{3} \mathrm{em} \mathrm{2007}$, por ano. Chichava (2010, p. 342) continua apontando que 50 a $70 \%$ da madeira correspondente a 1524 milhões de dólares americanos é explorada ilegalmente.

\section{RESUMOS}

Este artigo tem como objetivo avaliar os ganhos de Moçambique em sua relação diplomática com a China, à revelia da ideia vigente de que as ações deste país provoquem riscos para o desenvolvimento sustentável moçambicano. Partindo da análise da primeira fase de cooperação 
entre as duas nações desde os anos setenta, chegamos à avaliação dos ganhos para Moçambique oriundos deste diálogo dos anos 2000 aos dias atuais.

This paper aims to assess Mozambique's gains concerning its diplomatic relationship with China, ignoring the current idea that this country's actions may endanger the Mozambican sustainable development. From the analysis of the two nations' first phase of cooperation, since the 1970s, we were able to assess the gains for Mozambique derived of this cooperation from the 2000s to present day.

Cet article veut considérer les bénéfices obtenues par Mozambique dans ses rapports diplomatiques avec la Chine - en dépit d'un discours selon lequel les actions chinoises provoquent des risques pour la réalisation du développement équitable à Mozambique. A partir de l'analyse de la première fase de coopération entre les deux pays dans les années soixante-dix, on arrive à évaluer les avantages retirés de ce dialogue par Mozambique dès les années 2000 à nos jours.

Este artículo, tiene por objeto analizar las ganancias de Mozambique en su relación diplomática con la China, en contra de la idea vigente de que las acciones Chinas son causantes de riesgos para el desarrollo sustentable Mozambiqueño. Partiendo del análisis de la primera fase de cooperación entre los dos países en la década de 1970, son interpretados los actuales dilemas y realidades, en términos de los avances y ganancias de Mozambique en el ámbito económico internacional desde el año 2000.

\section{ÍNDICE}

Keywords: Mozambique-China cooperation, economic development, win-win cooperation, foreign policy, economic dependence.

Palavras-chave: cooperação Moçambique-China, desenvolvimento econômico, win-win cooperation, política externa, dependência econômica.

Mots-clés: coopération Mozambique-Chine, développement économique, win-win cooperation, politique extérieure, dépendance économique.

Palabras claves: cooperación Mozambique-China, desarrollo económico, cooperación "ganagana", política externa, dependencia económica.

\section{AUTOR}

\section{NELSON LAURA MABUCANHANE}

Doutorando de Políticas Públicas e Formação Humana (PPFH) - linha Estado e Políticas Públicas, na Universidade do Estado do Rio de Janeiro (UERJ). Docente de Políticas Públicas e Análise de Políticas Públicas no Instituto Superior de Administração Pública em Moçambique. Email: nelsonisap@gmail.com 